University of Rhode Island

DigitalCommons@URI

Open Access Master's Theses

1972

\title{
Man's Relationship to Nature and Society in Hawthorne's The Scarlet Letter
}

Sherry E. Adams

University of Rhode Island

Follow this and additional works at: https://digitalcommons.uri.edu/theses

\section{Recommended Citation}

Adams, Sherry E., "Man's Relationship to Nature and Society in Hawthorne's The Scarlet Letter" (1972). Open Access Master's Theses. Paper 833.

https://digitalcommons.uri.edu/theses/833

This Thesis is brought to you for free and open access by DigitalCommons@URI. It has been accepted for inclusion in Open Access Master's Theses by an authorized administrator of DigitalCommons@URI. For more information, please contact digitalcommons-group@uri.edu. 
MAN'S RELATIONSHIP TO NATURE AND SOCIETY IN HAWTHORNE'S

THE SCARLET LETTER

BY

SHERRY E. ADAMS

A THESIS SUBMITTED IN PARTIAL. FULFILLMENT OF THE REQUI REMENTS FOR THE DEGREE OF

MASTER OF ARTS

IN

ENGL.ISH

UNI VERSITY OF RHODE ISLAND

1972 


\section{MASTER OF ARTS THESIS}

OF

\section{SHERRY E. ADAMS}

Approved:

Thes is Comnittee:

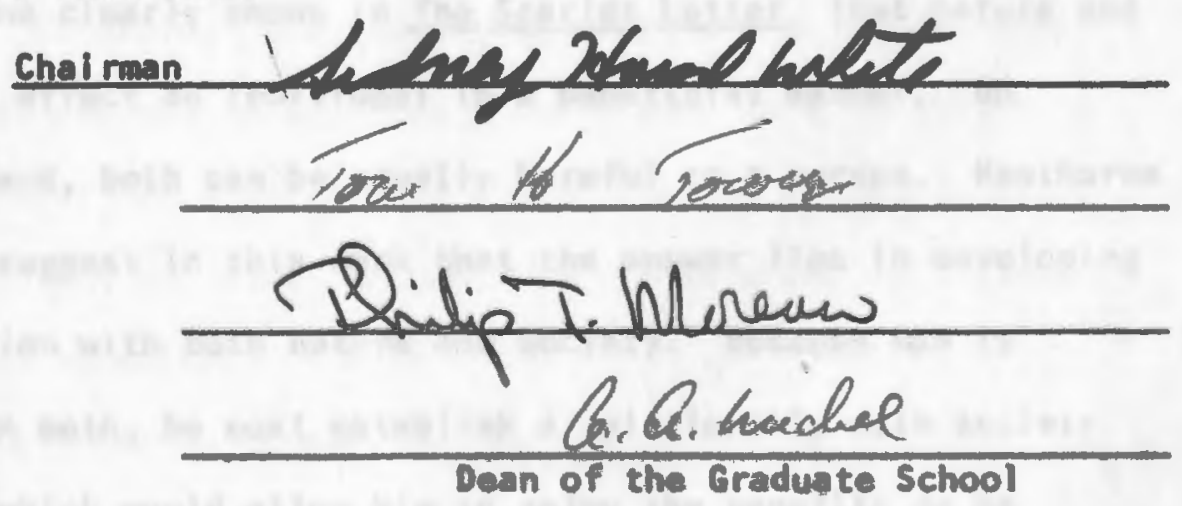

UNI VERSITY OF RHODE ISLAND 


\section{ABSTRACT}

Nathaniel Hawthorne's treatment of man's relationship to nature and society in The Scarlet Letter will be examined in this work. It will be necessary to examine Hawthorne's treatment of the beneficial and detrimental aspects of nature in his famous romance. In addition, a thorough study of Hawthorne's attitude toward the Puritan society will be made. Although Hawthorne deals exclusively with a community of Puritans in The Scarlet Letter, he appears to draw conclusions which would apply to any society at any time. A close analysis of each major character and his relationship to the community in which he lives and the physical universe around him will be essential to this study. Hawthorne's personal journals and letters add additional valuable information concerning his attitudes toward these subjects.

Hawthorne clearly shows in The Scarlet Letter that nature and society can affect an individual in a beneficial manner. On the other hand, both can be equally harmful to a person. Hawthorne appears to suggest in this work that the answer lies in developing an association with both nature and society. Because man is dependent on both, he must establish a relationship with society and nature which would allow him to enjoy the benefits to be gained from each while avoiding their inherent dangers.

A major problem in The Scarlet Letter results from the fact that all the major characters become isolated either from their 
society or from the natural universe. All these characters experience an alienation from their society. Hester is isolated as a result of her sin. Dimmesdale's sin and hypocrisy divorce him from his townspeople. Chillingworth lacks human sympathy which would link him to mankind, and Pearl allies herself exclusively with the forces of nature rather than society. All the characters suffer as a result of this alienation, and they all come to realize that they need to be a part of their society. Hester returns to her community to spend the last years of her IIfe. Chillingworth proclaims that his alienation from mankind has made him into a fiend. Pearl reconciles herself to the society after Dimesdale's confession restores his honest relationship to the community.

In the same manner, an isolation from the physical universe has tragic effects on Hawthorne's characters. When Hester and Dimesdale attempt to deny their natural passion and to isolate themselves from the physical universe, they find their efforts are futile. Dimnesdale grows weak and sick, and Hester's natural beaty is transformed to ugliness. Chillingworth's inability to associate himself with the strength and vitality of nature seems to cause his physical body, al ready old and deformed, to become shriveled and parasitic.

Hawthorne seems to suggest in The Scarlet Letter that an individual must find a harmonious balance between nature and society. He points out the benefits to be gained through a close alliance with both, but he clearly illustrates that an exclusive association with elther nature or society will be 
very detrimental. 


\section{ACKNOWLEDGMENTS}

I would like to express my sincere appreciation to my advisor, Dr. Sidney Howard White, for his help and guidance during the course of this study.

I am especially grateful to 01d Tom for caring enough to encourage me to do this. 


\section{TABLE OF CONTENTS}

CHAPTER

PAGE

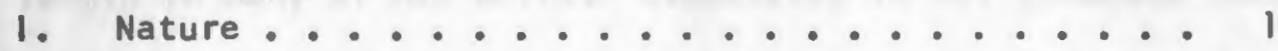

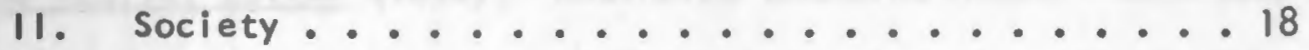

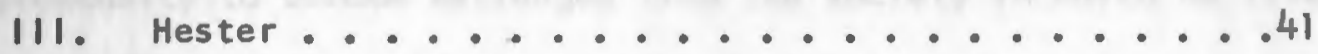

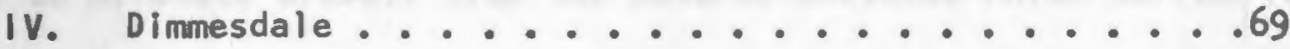

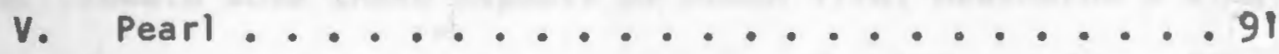

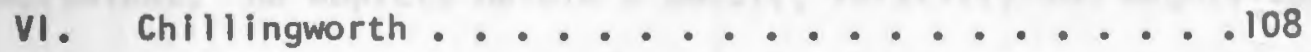

vIl. Conclusion ................ 122

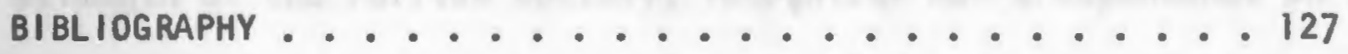


Nathaniel Hawthorne, whose personal life had been plagued by periods of seclusion and isolation, deals with these subjects at length in many of his works. Especially in his greatest romance, The Scarlet Letter (1850), Hawthorne concerns himself wi th man's propensity to become estranged from the society in which he lives or to alienate himself from the natural universe which surrounds him. Toward both these aspects of human life, Hawthorne's view is ambivalent. He depicts nature's beauty, fertility and magnificence while, at the same time, pointing out its lawlessness. He sees the strength of the Puritan society, recognizes man's dependence on it, and respects its attempt to achleve its lofty ideals. By the same token, he is quick to portray a society which is preoccupied with sin and which stifles creativity and individuality.

In The Scarlet Letter, Hawthorne's major characters are torn between these opposing aspects of life. Although dependent on both nature and society, his characters struggle to strike a precarious balance between the two. Hawthorne seems to suggest in his romance that this balance, tenuous as it is, is essential to a hamonious life. While Hawthorne's major characters in The Scarlet Letter experience an alienation from the harsh Puritan society, they also manage to serve that society in a beneficial manner. Hester, ostracized from society for her sin of adultery, 
sews for the poor and serves the sick. Dimmesdale, separated from his fellow man by his sense of hypocrisy and sin, is i ronically an outstanding spiritual leader. Chillingworth, alone in his intellectual world, is an able physician.

This same dilemma can be seen in man's relationship to his physical universe. Dependent on nature for beauty and strength and vitality, Hawthorne's characters must not sacrifice their sense of morality because of the lures of nature. Though Pearl's relationship with the physical universe is idyllic, she is saved from a life of isolation from society by Dimmesdale's ultimate confession of paternity. Hester also having been closely allied to nature, chooses to live the last years of her life within the confines of the Puritan society rather than in the freedom of the American wilderness or the vastness of a European city. Even Chillingworth maintains a fragile tie with nature, his source of medicine.

Thus, as R. W. B. Lewis points out, Hawthorne's characters are attracted to both "the village and the forest, the city and the country; for these are the symbols between which the choice must be made." I This macrocosmic conflict is paralleled by a microcosmic struggle between the heart and the head, or the emotions and the intellect. At odds with each other these two forces

'R. W. B. Lewis, "The Return into Time: Hawthorne," The furican Adan: Iwbocence, Tragedy and Tradition in the Nineteenth untury (Chicago: University of Chicago Press, 1955), p. 113. 
fight for supremacy within each of Hawthorne's major characters in The Scarlet Letter. Especially in the character of Hester is this struggle intense. An extremely emotional woman, she allows her passion to control her conduct and is severely castigated by the Puritan society as a result. Later, she attempts to smother the flames of her passionate nature and to exist in the realm of intellect. 'Much of the marble coldness of Hester's impression was to be attributed to the circumstance that her life had turned, in a great measure, from passion and feeling, to thought. $11^{2}$ Later, Hester returns to the opposite extreme by allowing herself to be ruled entirely by her emotions when she proposes that she and Dimmesdale flee the confines of the Purltan society. She hurls away the scarlet letter, imposed by her society as a constant reminder of her sin, and when she rejects that society and its concept of $\sin$, she feels an exquisite relief of both heart and mind. She loosens her hair and so silently proclaims her love and sexuality once again.

The same struggle occurs within Anthur Dimmesdale. His acute and sensitive intellect is at constant odds wi th his "strong animal nature" (p. 130). His intellect tells him that his passionate love is and has been sinful, but suffer as he might,

2Mathaniel Hawthorne, The Scarlet Letter, Centenary Edition of the Horks of Mathaniel Hawthorne, ed., Willian Charvat, Roy Wervey Pearce, and Claude M. Simpson, Vol. I (Columbus: Ohio State University Press, 1962), p. 164. Hereafter cited by page numbers in the text. 
he finds it impossible to be truly repentant. Dimmesdale's inner struggle is symbolized by his habit of holding his hand over his heart in an effort to stifle its passion and its pain. Chillingworth is a passionless man whose mind has long ago conquered his emotion. Hawthorne presents him as a character totally lacking in the quality of human sympathy, and the result is demoniac. By contrast, Pearl is ruled entirely by her own feelings. Though a potentially intelligent child, she behaves according to the dictates of her emotions, reacting to situations in an unpredictable and uncontrollable manner. The result, in the characters of both Chillingworth and Pearl, is dehumanization which suggests again that a balance between the head and the heart must be effected in order for life to be at all harmonious. The tragedy of Hester, Dimmesdale, and Chillingworth is that none is capable of reaching a point of equilibrium. They adopt one extreme or another as the answer to life.

The powers of the heart are equated with the forces of nature in The Scarlet Letter, and conversely, society comes to suggest the opposite extreme; the intellect. When Hester and Dimmesdale reject the laws of society and allow their emotions full rein, they are symbolically accepting the law of nature and following the dictates of their hearts. In other words, Hawthorne portrays nature as being as mysterious and untamed as human passion, while society is as cold and unfeeling as the human mind. Society, like the intellect, imposes restrictions on the 
natural impulses of human beings.

Hawthorne's work implies that neither nature nor society should have complete power over the individual. The danger of relying too much on the laws of nature is exemplified in the tragedy of Hester Prynne. Chillingworth, on the other hand, personifies the perils of letting the mind dictate behavior. Dominated entirely by his intellect, he loses the qualities of the human heart and therefore becomes separated from common humanity. Both extremes lead to the perilous position of isolation which is the greatest of the evils that Hawthorne can devise. Hester's complete rellance on the heart isolates her from the members of her society, and Chillingworth's total dependence on his intellect prohibits him from experiencing a deep sympathy with either nature or mankind. Hawthorne proclaims that one's "conscience might find it hard to strike a balance" between the head and the heart, but it must be sought (p. 200).

Hawthorne's own struggle to reconcile the extremes of nature and society, to strike a balance between the two, can be seen in a close analysis of the relationship that his four major characters have with the physical universe which surrounds them and the society in which they live.

The first chapter of this study will present a discussion of Hawthorne's attitude toward the physical universe. Drawing from his personal journals and The Scarlet Letter, the analys is will concentrate on Hawthorne's recognition of nature's bifurcation. The second chapter of this study will concentrate on the subject 
of society. The remaining chapters will be concerned with discussions of each of the major characters in The Scarlet Letter. Each chapter will illustrate how the characters are torn by the tension between the temptations of nature and the demands of society. Each character is involved in a struggle to reconcile these opposing forces. Hester, discussed in Chapter III, favors the freedom of nature but constantly struggles to establish some type of rapport with the community around her. Dimmesdale, the abject of Chapter IV, leans toward the opposite extreme. He not only embraces the codes of the Puritan society, but also helps to establish and enforce them. Pearl and Chillingworth will be discussed in Chapters $V$ and VI respectively. Each character represents an extreme point of view. While Pearl is exclusively a child of nature, Chillingworth lives within the realm of the mind only.

\section{2.}

Nathaniel Hawthorne presents a complex view of nature in The Scarlet Letter. The nature which surrounds the Puritan society is luxuriant and alluring. Its beauty is inviting, and it seems to promise all the joys of life. The sunshine which Pearl chases is filled with "splendor" and is a warm playmate for the vivacious child (p. 184). The moss in the forest is "luxuriant," providing a soft and lush seat for Hawthorne's tormented lovers (p. 186). Hawthorne himself had been attracted by such richness in nature. In his American Notebooks in 1842 be carefully describes nature's seductive beauty and rejoices in it. 
Oh that I could run wild:-- that is, that I could put myself into a true relation with nature, and be on friendly terms with all the congenial elements. 3

He praises and idealizes this aspect of nature and longs to recapture man's innocence in a modern Garden of Eden. Often his Notebooks refer to this ideal setting. Whlle living in Concord in 1842, he proclaims:

The natural taste of man for the original Adam's occupation is fast developing itself in me... I seem to have cast off all care, and live on with as much easy trust in Providence, as Adam could possibly have felt. (Notebooks, p. 153)

Hawthorne wants desperately to immerse himself in a joy-filled world of nature which is a re-creation of the Innocence of Eden. Darrel Abel has suggested that 'Hawthorne's honeymoon in the OId Manse seemed to him a renewal of an interrupted Iife in nature, a return to Eden. $11^{4}$ Hubert Hoeltje supports this view by pointing out the close friendship which developed between the Hawthornes and the Transcendental thinkers, by describing the idyllic environment of the 0Id Manse, and by stating that when Hawthorne and his bride lived in the famous old house, they lived with as much joy "as Adam and Eve could possibly have felt before they learned that there was a world beyond Paradise. 1.5 Carl Strauch notes that Hawthorne's work often "stresses the idyllic domestic exercise of

${ }^{3}$ Nathaniel Hawthorne, The American Notebooks, ed., Randall Stewart (New Haven: Yale University Press, 1932), P. 169. Hereafter cited as Notebooks in the text.

4Darrel Abel, "The Theme of Isolation in Hawthorne," Personalist, XXXI1, Pt. I (Winter 1951), P. 42.

5 Hubert H. Hoeltje, Inward Sky: The Mind and Heart of Nathaniel Hawthorne (Durham: Duke University Press), P. 198. 
love that evokes the divinely primitive innocence of the Garden of Eden." 6 Like Pearl, Hawthorne would love to be ignorant of human dishonesty and deceit, to know nothing of the Black Man, and to simplify his life to the point of existing "merely to live and to enjoy; and whatever is essential to life and enjoyment will come as naturally as the dew from heavern (Notebooks, p. 154). Hawthorne's eagerness to commune with nature is clearly seen in his American Notebooks; during the period of his living at the 0ld Manse, he often refers to himself as Adam and to his wife as Eve. He trusts that if he were "to look exclusively to (Nature) for the support of my Eve and myself... she would not fail me" (Notebooks, p. 154).

It is an interesting fact that Hawthorne "sometimes wrote seated in an antique elbow chair... which Emerson had used while he was living with old Dr. Ripley and writing much of Nature. "7 Emerson urges, in his famous essay of 1836, that man should "enjoy an original relation" to the universe. 8 Later, living in the same environment, perhaps writing in the same chair that Emerson had used, Hawthorne notes in his Journal on August 13, 1842, "It is as if the original relation between man and Nature

${ }^{6}$ Carl Strauch, "The Problem of Time and the Romantic Mode in Hawthorne, Melville, and Emerson, "Emerson Soclety Quarterly, XXXV (2nd Quarter 1964), p. 54.

7

Hoeltje, p. 197.

$8_{\text {Ralph Waldo Emerson, "Nature," The Complete Writings of }}$ loh Waldo Emerson (New York: Wm. H. Wise and Company, 1929), P. I. 
were restored in my case" (Notebooks, p. 154). It is more than mere coincidence that Hawthorne repeats Emerson's famous phrase. It is clear that Hawthorne yearns for the achievement of harmony between man and nature. He wants to experience, while living at the old Manse, all the purity, Joy, and inspiration which Emerson had pictured in his essay on Nature.

Hawthorne's characterization of Pearl shows the same desire. Pearl 'was worthy to have been brought forth in Eden; worthy to have been left there, to be the play thing of the angels, after the world's first parents were driven out" (p. 90). She relishes the beauty and vitality of the natural universe. She finds pure joy in the warmth of the sunshine and the caresses of the breeze. The animals in the forest accept her as a kindred spirit, and she personifies the idyllic innocence of nature before the fall. "The great black forest--stern as it showed itself to those who brought the guilt and troubles of the world into its bosom--became the playmate of the lonely infant, as well as it knew how" (p. 204).

In addition to the beauty and innocence of nature, Hawthorne finds comfort in nature's deep sympathy for mankind. Again and again in The Scarlet Letter, the physical universe seems to provide solace and support to a Hawthorne character. The wild rose bush, for example, outside the prison door, persists and blooms in a hostile society "in token that the deep heart of Nature could pity and be kind" (p. 48). This sympathy of nature is in sharp contrast to the harsh and unforgiving attl tude of the Puritan 
society which provided punishment to any offenders without the softening effects of understanding. The forest provides a haven of relief and new hope to Hester and Dimmesdale, away from the scrutiny of society. There, nature rejolces with the two lovers over their new freedom and recaptured love.

And, as if the gloom of the earth and sky had been but the effluence of these two mortal hearts, it vanished with their sorrow. All at once, as with a sudden smi le of heaven, forth burst the sunshine, pouring a very flood into the obscure forest, gladdening each green leaf, transmuting the yellow fallen ones to gold and gleaming adown the gray trunks of the solemn trees. The objects that had a shadow hitherto, embodied the brightness now. (pp. 202-203)

Such examples of Hawthorne's use of the pathetic fallacy are numerous in The Scarlet Letter, and they all suggest his delight in recognizing the deep sympathy of nature with man's emotional being. Shortly after his marrlage in 1842, he recorded the experience of such a close communion with nature.

Now the breeze is the gentlest sigh imaginable, yet with a spiritual potency, insomuch that it seems to penetrate with its mild, ethereal coolness, through the outward clay, and breathe upon the spirit itself, which shivers with gentle del ight. (Lotebooks, p. 104)

For Hester and Dimmesdale the brook sings mournfully of human sorrow and the trees were melancholy "while one solemn old tree groaned dolefully to another, as if telling the sad story of the pair that sat beneath" (p. 195). Thus nature mirrors this gloomy hour for the lovers, and they find comfort in the forest. When their despair turns to joy and hope, nature also reacts with a flood of sunshine. "Such was the sympathy of Nature" (p. 203). 
but also, and more importantly, with strength and life. Hawthorne is in awe of nature's vitality and power. He joyously recounts in his Notebooks the "infinite generosity and exhaustless bounty in our Mother Nature" (Notebooks, p. 162). It nurtures and supports mankind, providing an unending supply of shelter, water, and food. Even the warmth of the sunshine provides strength, and thus Hawthorne portrays his characters as dependent on nature for these essential gifts.

Indeed, sunshine especially has a deep significance to Hawthorne. Richard Harter Fogle writes an extensive analysis of the importance of sunlight and shadow in The Scarlet Letter, and he suggests that the "waxing and waning of sunlight in the forest scene symbolizes the emotions of Hester and Dimmesdale. "19 Yet Hawthorne's Notebooks suggest that it might have an even deeper significance. In 1843 he even considered it as the subject for a future short story.

The streak of sunshine journeying through the prisoner's cell; it may be considered as something sent from heaven to keep the soul alive and glad within him. And there is something equivalent to this sunbeam in the darkest circumstances; as flowers, which figuratively grew in Paradise, in the dusky room of a maiden in a great city; .. . God does not let us live anywhere or anyhow on earth, without placing something of heaven close at hand. (Notebooks, pp. 97-98)

Hyatt Waggoner believes that Hawthorne uses sunshine to represent something more than simple emotion. He states that in The Scarlet

9

Richard Fogle, Hawthorne's Fiction: The Liaht and the Dark (Norman: Oklahoma University Press, 1952), P. 140. 
Letter "sunlight suggests both truth and health."10

The flowers and even weeds of nature are sources of much needed medicines for both the body and the soul. The energy and vitality of Pearl, a true child of nature, are two of her most outstanding attributes, and when Pearl holds Dimmesdale's hand as they stand on the scaffold at midnight in May, "there came what seemed a tumultuous rush of new life, other life than his own, pouring like a torrent into his heart, and hurrying through all his veins, as If the mother and the child were communicating their vital warmth to his half-torpid system" (p. 153). There is no doubt that much of Dimmesdale's new-found energy can be attributed to his sense of relief from hypocrisy, but Pearl, like the forces of nature, obviously has the ability to refresh and renew the ebbing 11

energies of the tortured minister. Hawthorne recorded the phenomenon of being rejuvenated by nature in his Notebooks in 1841 . 'There is a very peculiar sense of warmth . . Where bright sunshine falls, and where green grass is seen among withered leaves. There is a feeling of shelter and comfort, and consequently a heartwa rmth" (Notebooks, P. 89). Pearl, in The Scarlet Letter, is a true child of nature and is much akin to a streak of bright sunshine.

10 Wyatt H. Waggoner, Hawtherne: A Critical Study (Cambridge: Harvard University Press, 1955), P. 125.

II It is interesting to note that this scene occurs in May, whereas the date of Governor Winthrop's death was actually in March. The rejuvenation of the minister would correspond, then, to the rebirth of spring. 
This inexorable ability of nature is in sharp contrast to the Puritan society which places the prison in the center of the town, suggesting the stifling sterility of the society as opposed to the magnificent fertility of nature. The contrast between these two aspects of life is great, and shows that Hawthorne is somewhat sympathetic to the romantic mood in New England in the mid-1800's. The first half of the Nineteenth Century was characterized by intellectual excitement and upheaval. In New England particularly, scholars were revolting against a past which had produced intellectual and cultural sterility. New ideas concerning God, society, the physical universe, and the individual himself were everywhere. Scholars became more and more critical of the Puritanism of their ancestors. Unitarianism eventually replaced strict Puritan beliefs, and as a result, attitudes toward the individual became more and more benign.

The writings of Emerson, the father of Transcendentalism, suggest that each man's individuality is precious and should be valued above his membership in society. Emerson argues that "the moral law lies at the center of nature" and not in society (Emerson, p. 13). In order to discover that moral law, a man "needs to retire as much from his chamber as from society" (Emerson, p. 2). Alone and free from the words and ideas of the past, "a wild delight runs through the man" when he strengthens his association with the physical universe (Emerson, p. 2). Emerson urges man to realize that his relationship to nature is more beneficial than his relationship with society. He states that "in the wilderness, 
I find something more dear and connate than in streets or villages" (Emerson, p. 3). Nature, he believes, benefits both the senses and the soul. Emerson's goal is to have mankind enjoy a harmony with the physical universe. He argues that by developing a close communion with nature, man will be able, intuitively, to recognize philosophical and moral truths. He will recapture his sense of individuality and self-reliance.

To the Transcendentalists, then, the physical universe has a beneficial, moral, and joyous influence on mankind. Surrounded by the optimism of Emersonian Transcendentalism, Hawthorne was well aware of nature's benevolence. He, like many of his Concord compatriots, was anxious to praise the beauty, purity, vitality, and fecundity of nature, and he enthusiastically endorsed the idea of a sympathy between man and nature; but, unlike other thinkers of his time, he could not embrace the overriding optimism of an entirely benevolent physical universe. He had too complete a knowledge of the world around him for that. In fact Hawthorne satirizes the optimism of Transcendental reformers in The Blithedale Romance (1852). Their eagerness to create a utopia by placing man in a pure environment without finding some means to "purify the heart of man" is considered folly by Hawthorne (Waggoner, p. 175). The same satirical treatment of Transcendentalists can be seen in "The Celestial Railroad" (1846). Hawthorne does not consider man to be entirely pure, nor does he view the natural universe as completely benevolent. 
Consequently, The Scarlet Letter gives its reader a clear understanding of nature's beneficence, but it also presents, at the same time, a stark portrayal of nature's mysterious bifurcation. Near the rose bush outside the prison door, Hester might have noticed the "grass-plot, much overgrown with burdock, pigweed apple-peru, and such unsightly vegetations, which evidently found something congenial in the soil" (p. 48). Hawthorne recognizes that nature is capable of presenting mankind with beauty and ugliness, goodness and wickedness, purity and evil, sympathy and cruelty, all at the same time. Hester, too, was amazed at the idea that Chillingworth could find medicinal herbs and roots in the ground, and she imagined that the same plot of earth would produce, after his footstep, "deadly nightshade, dogwood, henbane, and whatever else of vegetable wickedness the climate could produce, all flourishing with hideous luxuriance" (p. 176).

This duality is especially apparent in the forest. Though Pearl innocently and idyllically plays there, it is also the home, in Tha Scarlet Letter, of the malevolent Black Man who lurks there in anticipation of human prey. Pearl describes him by saying that he haunts this forest, and carries a book with him,--a big, heavy book with iron clasps; and... this ugly Black Man offers his book . . . to every body that meets him here among the trees; and they are to write their names with their own blood. And then he sets his mark on their bosoms! (pp. 184185).

This forest which can be a haven of beauty and inspiration is also portrayed by Hawthorne as "black and dense" (p. 183). It is a "dismal" place of mystery which leads to "intense seclusion" (pp. 187-188). The threat of intense seclusion is an ominous one 
in this work so deeply concerned with isolation, for once one has lost contact with humanity around him, he is in dire danger of losing sight of moral and ethical truths. Thus as Hester and Dimmesdale, secluded in the forest, enjoy the loveliness and sympathy of nature, they also are in danger of falling prey to its lawless immorality. "That wild, heathen Nature of the forest, never subjugated by human law, nor illumined by higher truth" could mislead men by allowing them to be ruled by their hearts alone (p. 203). Waggoner points out that "the imagery here suggests that moral law and nature's ways do not perfectly coincide, or run parallel on different levels; they cross, perhaps at something less than a right angle. At the point of their crossing the lovers' fate is determined" (Waggoner, P. 125).

Lovely and inviting, the forest is a place of temptation in The Scarlet Letter because society's strict moral and civil laws do not penetrate nature's dense domain. In addition, Hawthorne points out that nature, with her vital powers and forces, is sympathetic to love and life and passion, but not to moral or aesthetic considerations. In an undated entry in his Notebooks, Mawthorne, laments:

Nothing comes amiss to Nature--all is fish that comes to her net. If there be a living form of perfect beauty instinct with soul--why, it is all very well, and suits Mature well enough. But she would just as lief have that same beautiful, soul illumined body, to make worm's meat of, and to manure the earth with. (Notebooks, p. 118)

Thus nature has little sympathy with Dimmesdale's sensitive, aesthetic character. Inspiring him to ignore his intellect and 
the strictures of his society, nature encourages the minister to recognize and express the natural passion within him.

For Hawthorne then, nature is many things. It is beauty, freedom, strength, sympathy, and idyllic innocence. It is also mysterious, dismal, lawless and potentially evil. More than this, nature is a place of moral cholce. 
Nathaniel Hawthorne shows great concern in his writing for man's relationship to his society. He shares the interest of the Transcendentalists in attempting to find the ideal relationship between an individual and the community in which he lives, and in The Scarlet Letter he studies the unique American society of his Puritan forefathers which combined moral and civil laws into one. Although Hawthorne limits his discussion to the Puritan society, he clearly establishes his belief that an individual will always need to be a part of some type of society. He emphatically illustrates the tragic consequences of isolation from mankind. Nevertheless, Mawthorne harshly criticizes several aspects of the Puritan community. The criticisms which Hawthorne points out pertain specifically to the Puritan society, but they appear to suggest flaws that an ideal society would have to avoid.

His treatment of the Puritan society in this romance has led scholars and critics to varying conclusions concerning Hawthorne's view of this society. Roy R. Male sees him as both "a defender of Puritanism who satirized his ancestors" and as "a Romantic who attacked Transcendentalism."l Stewart presents him as a "Puritan,

'Roy R. Male, Huwthorne's Traaic Vision (New York: W. W. Norton and Company, ig57), p. 18. 
perhaps the Puritan of Puritans among the great American writers.112 George E. Woodberry states that Hawthorne, who was no Puritan in doctrine or sympathy even, was Puritan in temperament. "13 Edward Megenknecht holds the opinion that Hawthorne "is a Puritan, but he is a Purltan only in a general way" because he "did not believe that law can deal with the sins of the soul.1" 4 Though many critics regard him as generally supporting the Purltan philosophy, Hawthorne's family repeatedly rejected the idea. Lewis finds that Hawthorne held some of the views expressed by Jonathan Edwards and that he also agreed with some of the Ideas stated by Ralph Waldo Emerson. 5 Hoeltje finds Transcendental characteristics in the writings of Hawthorne and suggests that he has a great deal in common with Emerson and Coleridge. ${ }^{6}$ No doubt the debate will continue. 7

2 Randall Stewart, "Puritan Humanism vs. Romantic Naturalism," Mrican Literature and Christian Doctrine (Baton Rouge: Louisiana , to trersity Press, 1958), rpt. in Nathaniel Hawthorne, The Searlet Letter, ed. Sculley Bradley, Richmond Croom Beatty, and E. Ciudson Long (New York: W. W. Norton $\&$ Company, 1962), p. 345 . Hereafter cl ted as "Puritan Humanism."

3

George E. Woodberry, Nathaniel Hawthorne (Boston: Houghton, Mifflin and Company, 1902), p. 199.

HEdward Wagenknecht, Cavalcade of the American Novel (New York: Holt, Rinehart and Winston, 1952), Pp. 54-55.

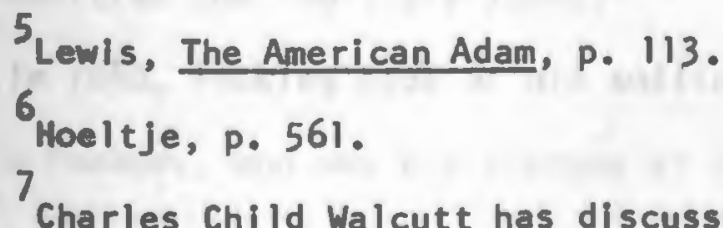
opinions and interpretations of The Scarlet Letter in 'The Scarlet Letter and its Modern Critics," Mineteenth Century Fiction, VII (1953), 251-64. Frederic 1. Carpenter has discussed the same subject in "Scarlet A Minus," College English, V (January 1944), pp. 173-180. 
The earnest student searches through Hawthorne's Notebooks in vain looking for an answer to this controversy. Unlike Emerson, Hawthorne did not ponder philosophic concepts in his journals. Instead, he made careful and detalled observations of people and things around him in hopes that his notes could be incorporated into a tale or romance. Hawthorne also jotted down possible subjects or names for characters in his notes. His Notebooks are practical, not philosophical; and if an answer to this debate is to be found, it must be discovered through a close analys is of Hawthorne's fiction rather than his journals.

The Scarlet Letter is intensely involved with man's relationship with his society, thus suggesting how deeply Hawthorne was concerned with the subject. His own life had been filled with solitude and loneliness, especially during the period from 1825 to 1837. After graduating from college, Hawthorne spent the next dozen years in relative seclusion, studying, reading, and writing. He did enjoy the company of his family, and he took brief vacations annually, but for the most part, his energies were spent on perfecting his art. In his biography of Hawthorne, Stewart presents an excellent discassion of Hawthorne's period of isolation in a chapter entitled the "Solitary Years."18

In 1840, looking back on his solitude, Hawthorne confessed to Sophia Peabody, who was his fiancée at that time, 'Here I sat a

8 Randall Stewart, Mathaniel Hawthorne: A Blography (New Haven: Yale University Press, 1948), Pp. 27-44. Hereafter cited as Utheniel Hawthorne. 
long, long time waiting patiently for the world to know me... It seemed as if I were al ready in the grave, with only life enough to be chilled and benumbed. 19 clearly, the implication is that the Ilfe of active participation in society is preferable to one of isolation and passivity. Hawthorne had come to this conclusion earlier in his life, for in the flrst issue of The Spectator. Hawthorne's boyhood attempt at a weekly magazine, there appears an essay "On Solitude." This ambitious attempt at journalism was undated and appeared handwritten on small notepaper. More sophisticated editions of The Spectator appeared in 1820, indicating that Hawthorne's essay "On Solitude" was written sometime in his fifteenth year. The conclusions of this essay foreshadow those presented in the masterpiece of his maturity, The Scarlet Letter.

Young Hawthorne proclaims:

Man is naturally a sociable being; not formed for himself alone, but designed to bear a part in the great scheme of nature. All his pleasures are heightened, and all his grlefs are lessened, by participation. It is only in Society that the full energy of his mind is aroused, and all its powers drawn forth. 10

Hawthorne states that man is, therefore, dependent on his soclety in order to experience life to its fullest. Men are irrevocably linked to each other intellectually and emotionally, and consequently form a bond of brotherhood. The threat of isolation is terrifying for Hawthorne, and it concerns him from his

9 Stewart, Nathaniel Hawthorne, p. 36. 10 Hoelt je, pp. $45-46$. 
boyhood through his maturity. In 1854 he writes about Tennyson in his journal as having "the natural morbidness of a man who shirks society." Isolation is, to him, joyless and morbid for it denies a person full participation in life. "For Hawthorne, the unforgivable sin was spiritual isolation, the breaking of the magnetic chain of being."12 In much of his fiction Hawthorne "deals with the hidden fears of the solitary, the withdrawn, those committed to a point of view which denies the common human brotherhood, those wrestling with the age old problems of humanity in the isolation of the private soul..$^{13}$ There could not be a more tormented state than Hawthorne's portrayal of a man who longs to become an active participant in his society, but who is denied the privilege. 'The unrelieved painfulness which distressed even Hawthorne [in The Scarlet Letter] results from the fact that every one of its characters is segregated from the common 1ife. 114 Hawthorne presents his jor characters in The Scarlet Letter as longing for full acceptance in the Puritan community. Dimmesdale especially needs to live in truthful harmony with his towns-

"Newton Arvin, ed., The Heart of Hawthorme's Journals (Boston: Houghton Miffl in Company, 1929), P. 163.

12 Daniel Aaron, "Emerson and the Progressive Tradition," Aa. A Collection of Critical Essays, ed. Milton R. Konvitz Stephen E. Whicher (Englewood Cliffs: Prentice Hall, 1962), p. 88.

13 Wilson 0. Clough, The Mecessary Earth: Nature and Solitude in American Literature (Austin: University of Texas Press, 1964), p. 123.

14

Lawrence Sargent Hall, Hawthorne: Critic of Soolety (Gloucester: Peter Smith, 1966), P. 167. 
people. Hester, denied access herself, longs to hear her child laughing and playing with other children in the community. Even Chillingworth has made an attempt to join society by marrying Hester.

While all three characters want to share the bond of common humanity, at the same time, they all avoid it. Dimmesdale cannot muster the moral strength necessary for a confession. Hester's freedom of thought has made her critical and even suspicious of the purity of the community's moral and civil leaders. Chillingworth has developed his intellect to the point that his heart is no longer deeply sympathetic with mankind. Again, Hawthorne places his characters between two extremes. They long for harmonious acceptance in the community, but are repelled by society's demands. In the same manner, they are attracted to the beauty and vitality of nature, but are frightened by its lawlessness. Their struggle is, of course, to strike a balance between the head and the heart, and between the natural world and that of society.

It is important to remember that Hawthorne was writing in a period which was intellectually and actively seeking the ideal relationship between man and society. We have al ready noted the Transcendental attitudes toward self-reliance and society. "The great American writers of the Nineteenth Century recognized the divisive tendencies in their society and were deeply concerned 
about them."15 For Emerson, no less than for Hawthorne, "the debate between 'society and solitude' went on inside his mind for all his life."16 However, while Emerson concludes that "society is fatal," Hawthorne feels that it is essential (Emerson, p. 626). Whi le Emerson and Thoreau proclaim the advantages of complete self-reliance, Hawthorne depicts the pain of loneliness and isolation. While Emerson states that "society everywere is in conspi racy against the manhood of every one of its members," Hawthorne finds it an essentlal element in the full development of an individual (Emerson, P. 139). Hawthorne does, however, join his contemporarles in his criticism of their Puritan ancestors and their strict, demanding society. He shares the idealism of his neighbors in that he is "acutely critical of society," but he is not so zealous as to reject its good points (Hall, P. 2).

Emerson and Thoreau concentrate on the achievement of ideal existence through the devlopment of individual self reliance and a strengthening of man's ability to create an ideal society which will provide the moral and intellectual strength necessary for full individual development, and will also provide the joys of nature by allowing for individual creativity and freedom. Most important,

\section{Aa ron, p. 88.}

16 Perry Miller, ed., The American Transcendentalists: Their Prese and Poetry (New York: Doubleday and Company, 1957), Ap. 286-287. 
it will encourage understanding and love by strengthening the common bond of humanity and thereby building an indestructible foundation for itself.

The Puritan community falls far short of the ideal, and yet Hawthorne's treatment of the society has led to conflicting interpretations concerning his acceptance or rejection of Puritanism. Hawthorne's attitude is ambivalent. In order to understand his simultaneous condemnation and admi ration of the Puritan society it is necessary to discuss the basic Puritan theological concepts. Secondly, we must recognize Hawthorne's respect for the solld strength of the Puritan political system. The third point, however, and the one most effectively presented in The Scarlet Letter is the detrimental effect wich the Puritan society has on the individuals within it. Hawthorne is contemptuous of this society's emotional restraints on its members. It forces them to deny the physical aspect of their lives and confines them to living through the intellect alone. Because it does not allow for Individual freedom emotionally or intellectually, it does not achieve the ideal--the ideal which Hawthorne credits its leaders with having dreamed of.

Puritan society in The Scarlet Letter is based on stern theological concepts and laws which are strictly enforced. "It is clear that Hawthorne knew the history of New England well enough to imagine it symbolically"l and to have a firm knowledge of the basic distrust which the Puritans felt for the natural world around them (Male, P. 40). The Puritans based their faith on the concept of 
original sin and, therefore, believed that man in his natural state is corrupt. Consequently, if a man were to live according to the dictates of his own nature, he would inevitably live a life of sin. The Puritan concept of natural liberty, then, is contrary to their concept of civil liberty. John Winthrop explained the difference between the two terms by stating that "individuals in a natural state, before grace has been given them, are at absolute liberty to do anything they can, to lie, steal, murder." Perry Miller adds that Winthrop is "certain that natural men, being what they are, will do exactly these things unless prevented."17 The government, however, created by the people and bound by the law of God, provides men with civil liberty which means that they "renounce all natural liberty, surrender the right to seek for anything that they themselves might lust after, and retain only the freedom that is maintained and exercised in a way of subjection to authority." The law of nature, according to the Puritans, would encourage man to follow his instincts and passions and he would, as a result, lead a corrupt life. The civil law, on the other hand, would provide man with the "liberty to do only what God comands." 18 Hawthorne presents the dialectic between nature and society as providing an inevitable conflict for his characters.

17 Perry Miller, ed., The Puritans, rev. ed., Vol. I (New York: Harper and Row, 1963), P. 189.

18 Miller, Puritans, pp. 189, 190. 
Al though they are naturally inclined to seek the freedom of the wilderness, they earnestly seek the salvation promised by society and need "always to maintain contact with the magnetic chain of humani ty" (Waggoner, p. 259).

As a result of this conflict, the Puritan community in The Scarlet Letter is in sharp contrast with the world of nature which surrounds it. In fact, each of the characteristics of the community is diametrically opposed to the promises of nature. While the natural world is beautiful and inviting, the Puritan society is dark, somber and grim. The heart of nature seems to have a deep sympathy with mankind, and the Puritans are harsh and unforgiving. The sunshine of the forest promises joy and freedom as opposed to the stern adherence to society's laws enforced by the Puritan elders. Society, however, provides an individual with needed companionship while the forest can be a place of solitude and loneliness. While the freedom of the forest provides opportunity for good and evil Indiscriminately, society's laws are intended to direct an individual toward purity.

These laws and regulations, which individuals were compelled to respect, were intended to purge the society of $\sin$. We can have no doubt that Hawthorne has a deep respect for the Puritan goal of creating a perfect society. Charles Feidelson points out that "Hawthorne does full justice to the moral seriousness, the strength of character, and the practical ability that 
their way of thinking could foster."19 Hawthorne praises their earnest seriousness in the attempt to purify the society, and he suggests that the Nineteenth Century would do much worse by adopting an attitude "of mocking infamy and ridicule" (p. 50). The practices and punishments of the Puritan society are all based on moral principles and are thus dignified. In addition, the Puritan forefathers had built a solid and lasting community which would withstand many hardships. In the early years of the colony, the leaders had

been not often brilliant, but distinguished by a ponderous sobriety rather than activity of intellect. They had fortitude and self-reliance, and, in a time of difficulty or peril, stood up for the welfare of the state like a line of cliffs against a tempestuous tide ... The mother country need not have been ashamed to see these foremost men. (p. 238)

It is not the founding principles of the colony which Hawthorne criticizes, nor is it the Puritan goal of perfection; it is the means they use in attaining it that he finds reprehensible.

"At the head of the social system, as the clergymen of that day stood," the minister serves as an Interpreter and enforcer of God's law (p. 200). The importance of the clergy is clearly illustrated by Hawthorne as he portrays Hester's punishment before the Puritan society. Reverend Dimmesdale, Governor Bellingham accompanied by his four sergeants, and the famous John Wilson, a Congregational minister of Boston, are elevated

${ }^{19}$ Charles Feldelson, Jr., "The Scarlet Letter," Hawthorne Catenary Essays, ed. Roy Harvey Pearce (Columbus: Ohio State Eniversity Press, 1964), p. 48. 
above the Puritan community by means of a kind of balcony. Though their separation from common men is symbolized by Hawthorne's staging of this scene, they must judge and punish the townsmen, including Hester Prynne. Because of their preoccupation with laws and sin, and because of their over-developed intellectual powers, Hawthorne finds them ill-equipped to judge in affairs of the heart.

They were, doubtless, good men, just, and sage. But out of the whole human family, it would not have been easy to select the same number of wise and virtuous persons, who should be less capable of sitting in judgment on an erring woman's heart, and disentangling its mesh of good and evil. (p. 65)

The civil and moral laws are so closely related in this society that the governor and minister together oversee Hester's public punishment and later deliberate over Hester's ability to raise her child. "At that epoch of pristine simplicity . . matters.. of far less intrinsic weight than the welfare of Hester and her child, were strangely mixed up with the deliberations of legislators and acts of state" (p. 101).

Waggoner suggests that the "Governor's mansion seems obscurely to be the heart of the Puritan rulers'l (Waggoner, P. 136). No doubt he used the word "heart" ironically, for Hawthorne suggests that the stronghold of Puritan government as symbolized by the Governor's mansion is deficient in human sympathy and love. The mansion is decorated by a "row of portraits.. all were characterized by the sternmess and severity which old portraits so invariably put on; as if they were the ghosts, rather than the 
pictures, of departed worthies, and were gazing with harsh and intolerant criticism at the pursuits and enjoyments of living men" (p. 105). These Puritan worthies are all respected and revered, and are totally devoid, both 1 iterally and figuratively, of joy or hope or heart. Of particular note in the Governor's main hall is his suit of mall, which illustrates the Governor's hard, coarse exterior, and suggests that his attitude toward governing is stern and strict and physical. It has an impressive facade, but it is completely lacking in the qualities of the heart. When she sees her reflection in the highly polished suit of mail, Hester notes that "the scarlet letter was represented in exaggerated and gigantic proportions, so as to be ... the most prominent feature of her appearance. In truth, she seemed absolutely hidden behind it" (p. 106). In this manner Hawthorne illustrates the Puritan practice of exaggerating the importance of sin and guilt. The "follo tome" which also decorates the Governor's hall further symbolizes the propensity of the Puritan fathers to develop their minds and to ignore their hearts (p. 105).

It is interesting to note also that all of the furnishings of the mansion connote a reverence for the past and no apparent interest in the future. The Governor, who is dressed "in the antiquated fashion of King James's reign" had bullt his mansion as an imitation of the estates in England, and he had also made an attempt to cultivate an English ornamental garden to border the 
house (p. 108). The tome on the hall table, Hawthorne suggests, is "probably the Chronicles of England" in which the learned fathers can concentrate on past ages rather than the problems of the present ( $p$. 105). The row of portraits on the wall represents "the forefathers of the Bellingham IIneage" who look disapprovingly on the pursuits of the present and seem to demand the strict adherence to the practices of the past (p. 105).

In addition, Hawthorne's treatment of this scene suggests that the Puritans placed great importance on appearances, but appearances often belie the truth. The Governor's armor, "burnished to glow with white radiance" appears to represent the strength of the Puritan faith, but just as it is impregnable, it is also completely hollow (p. 105). Behind the strong and pure white exterior lies nothingness. In the same vein, the mansion itself is one of cheerful and bright exterior, but the inside is dismal. Waggoner states that "there would seem to be in this mansion an exaggerated consciousness of $\sin$ and almost no awareness of goodness" (Waggoner, P. 136). The Governor, "so rigid and severe, and frost-bitten with more than autumnal age," appears to care little for luxury (p. 108). Hawthorne is quick to point out, however, that

it is an error to suppose that our grave forefathers-though accustomed to speak and think of human existence as a state merely of trial and warfare, and though unfeignedly prepared to sacrifice goods and 1 ife at the behest of duty-made it a matter of conscience to reject such means of comfort, or even luxury, as lay fairly within their grasp. (p. 108)

Governor Bellingham argues that Pearl should be taken away from Hester so that she can be dressed properly and disciplined 
strictly; and last of all, he mentions the idea of her being taught God's truths. The punishment chosen for Hester is one which alters her appearance, and when she wears the scarlet letter and assumes the guise of humility, the members of society are pleased with the results of the punishment, never realizing that Hester's emotional and intellectual reactions are the opposite of what they had intended. Woodberry states that in Hawthorne's judgement Puritan punishments failed because they were based on physical appearances.

Hester's punishment is visibly from the law, and illustrates the law's brutality, the coarse hand of man for justice, the mere physical blow meant to hurt and crush; it is man's social way of dealing with sin, and falls because it makes no connection with the soul.20

The Puritan society is overly concerned with the punishment of sins, and as a resuit its very concept of the human condition is negative rather than affi rmative. As Feidelson points out, "the scaffold, situated 'nearly beneath the eaves of Boston's earliest church,' is the center of the society. Not once in the book is a church physically described or a scene actually staged within it" (Feidelson, p. 47). Furthermore, there is no place in this society so rooted in religion for the hopefulness of prayer. "The ministers do not urge Hester to seek divine support, but only to suffer her punishment, repent her transgression, and name another sinner" (Feidelson, p. 47). Thus Hawthorne finds the 
hopeful affirmation of life so prevalent in the beauty of nature to be sorely lacking in Puritan society.

Punishment is considered so important that the social leaders appear totally devold of symathy or mercy. Fogle has suggested that Hawthorne symbolized society's harshness in the opening scene outside the prison door. "The rose is pitying nature, as the prison is pitiless man." 21 The punishment given to Hester is brutal because it lasts for a lifetime and leaves no room for forgiveness. While Hester pleads, 'Let God punish! Thou shalt forglve!" the Puritan leaders and judges remain coldly dispassionate (p. 194).

Hawthorne's description of the Puritan environment suggests that the collective heart of the Puritan society has petrified into stone. Correspondingly, the town is built of heavy oak and iron. Surrounding the prison, the townspeople seem magnetized by the "i ron-clamped oaken door." The "grim rigidity" of that age has "petrified the bearded physiognomies" of the men. The pillory, a contrivance of wood and iron," is an effectual agent in the promotion of good citizenship." The women are "hard-featured" and "iron-visaged" (pp. 49-55). The Governor's doorway displays an "i ron hammer" which summons a "slave" (p. 104). Feidelson suggests that the Puritans seem "closer to the inorganic forms of stone, metal and dead timber than to the mind of God" (Feidelson, p. 50).

${ }^{21}$ Fogle, Hawthorne's Fiction, p. 14. 
There is no place for softness or sympathy in their composition.

More concerned with sin than with salvation, they consider taking Pearl from Hester to be "clad soberly, and disciplined strictly, and instructed in the truths of heaven and earth" (p. 110). By denying Hester her chlld, the Puritan elders would take away her means of redemption. Dimmesdale has to remind them of God's mercy in providing a child "to keep the mother's soul alive, and to preserve her from blacker depths of sin into which Satan might else have sought to plunge her" (p. 114). It is to their credit that Reverend Wilson and Governor Bellingham recognize the efficacy of Dimmesdale's plea, and that they allow Hester to keep her child and thereby provide her with a purpose in life.

The Puritans live "in a land where iniquity is searched out, and punished in the sight of rulers and people" (p. 62). The act of dragging the heart's secrets into the sunshine for public display is an obvious and unnecessary cruelty in Hawthorne's eyes. There is "no outrage more flagrant than to forbid the culprit to hide his face in shame" (p. 55). When the Puritans attempt to probe into Hester's heart to find the name of her child's father, when Chillingworth pries into the depths of Dimmesdale's heart, they all commit a sin far worse than one of passion. They have "vlolated, in cold blood, the sanctity of a human heart" (p. 195). Magoner points out that "If the bringing out of the heart's secrets into the light is forced, and not voluntary, it cannot be, in Mawthorne's scheme of values, beneficial" (Waggoner, p. 135). Hawthorne urges his reader to "Be true! Be true! Show freely 
to the world, if not your worst, yet some trait whereby the worst may be inferred!" (p. 260). Hester, however, is forced to her public confession, and the result is intellectual and emotional rebellion. She senses that Dimmesdale's confession will have to come of his own volition and therefore will not allow his name to be wrenched from her heart. When he does finally choose to confess, his reaction is quite the opposite of Hester's. Dimmesdale is restored by his confession to a full and honest relationship with the community. We can see that Hawthorne supports the theory of voluntary public confession, but he deplores the practice of forcing one to confess. The result of a voluntary confession is a renewed communication with humanity. "Reunion with his fellow man, which Hawthorne constantly sought and unfailingly recommended, was the first step toward freedom from the dungeon of self-sufficiency."22 A close and honest relationship with one's society appears, then, to Hawthorne to be the necessary element to a harmonious life. Although the major characters in The Scarlet Letter long for such an association, they are at the same time impeded by their own waknesses and repelled by the faults of their community.

Perhaps the worst fault of the Puritan society in Hawthorne's eyes is the undue severity of their code of conduct and the absolute negation of all the beauty and joy in the world of nature. Of the

22 Manry 6. Fai rbanks, The Lasting Loneliness of Nathanlel H. A study of the Sources of Allenation in Modern Man 4t: Maglbooks, 1965), P. 81. 
two scenes which deal with the entire Puritan community, the first depicts Hester's punishment, and the second is in celebration of Dimmesdale's Election Day sermon. Both are staged in the market place, and both have the scaffold as their focal point. Hawthorne thus implies the Puritan obsession with $\sin$. The women who await Hester's appearance on the day of her punishment exhibit a perverse enjoyment of her agony. School has been dismissed for the occasion, and the Puritans have declared a twisted sort of holiday as a result of Hester's sin and "In honor" of her punishment.

Hawthorne's treatment of both these occasions clearly illustrates the Puritan inability to experience joy. Waiting for Hester's appearance on the day of her punishment, the townspeople, dressed "in sad-colored garments," are characterized by a "grim rigidity" (pp. 47, 49). While nature promises joy and moral lawlessness, the Puritans are emotionally choked by the "dismal severity of the Puritanic code of law" (p. 52). In the later holiday scene, the Puritans make an obvious effort to be joyous, but they have lost that precious ability. Hester points out that in celebration of the Election Day sermon, "the children have come from their schools, and the grown people from their workshops and their fields, on purpose to be happy" (p. 229). Pearl, however, notes that the blacksmith "looks as if he would gladly be merry, if any kind body would only teach him how!" (p. 228). Hawthorne adds that in celebration of this inauguration, the Puritans "appeared scarcely more grave than most other communities at a period of general affliction" (p. 230). Even the Puritan children are ig* norant of the art of enjoyment. Hawthorne describes the children 
as "disporting themselves in such grim fashion as the Puritanic nurture would permit; playing at going to church, perchance, or at scourging Quakers" (p. 94). Hawthorne's humor here implies that the repression of joy is as reprehensible in its way as the lawlessness of nature. The solution, of course, would be a balance between the happiness of nature and moral structure of society.

The result of the grim joylessness encouraged by Puritan society is a loss of natural beauty and vitality. Hawthorne's portrayals of the Puritans verge on the grotesque. The women, particularly, lack refinement and speak with "boldness and rotundity." They are sturdy stock who have repressed their femininity and are now "man-like" (p. 50). Even Hester loses her vibrant beauty when she assumes the proper Puritan guise; and she adopts a "bare and harsh outline, which might have been repulsive, had she possessed friends or companions to be repelled by it" (p. 163). Hawthorne considers this attempt to suppress sexuality as detrimental to the society as well as the individual. Henry Fairbanks has stated that "America regarded suppression of sex as its greatest triumph. Sexlessness was its stamp of approval on all the forms of life: art, language, education."23 The price of sexlessness is, of course, moribundity. The petrified heart of socity is one which denies physical life and is bound to the ideas of the past.

${ }^{23}$ Fai rbanks, p. 122. 
This attitude inevitably leads to sterility in all aspects of the Puritan society. We have al ready noted the dependence of the Puritans on the past. The architecture of their Governor's mansion is a replica of an estate in England. The books chosen for display and study are those which look back at the past rather than into the future. The Puritans have closed their minds to new ideas or to actions which would disagree in the least with their own.

In this stagnant atmosphere the garden behind the Governor's mansion cannot flourish and grow. There is no fertility "in a hard soil" such as that found in the Puritan community (p. 106). "For all of them 'civilized life' consists of putting nature into prison, but the prison itself, the 'black flower' of their town partakes of the subhuman nature they condemn and obsessively scrutinize" (Feidelson, p. 50). Indeed Hawthorne suggests that this rigid society corrupts nature's normal beauty and fertility. We note that weeds and "unsightly vegetation" flourish in the center of the town and in the Governor's garden (p. 48). 'Meanwhile, natural affection, the red flower lives unwanted and disclaimed, in the heart of $\mathrm{Mr}$. Wilson and in the potential 'heart of the multitude'" (Feidelson, p. 51).

The negativism of the Puritan community denies the affirmation of fertility in nature and of sexuality in humans. It inevitably binds them to the past because it denies them the affirmation of the future. Boston itself had been built with the cemetery and the prison as among the "earliest practical necessities" (p. 47). Both are placed prominently in the center of town. Feidelson points 
out that the Puritans, "though they stand outside the prison have all the demeanor of prisoners" (Feidelson, p. 47). Because they have cultivated their minds at the expense of their hearts, because they have severed the bond of brotherly love and sympathy and replaced it with unbreakable laws, their hearts are joyless and their faces are grim. Just as their clothes lack color, so too do their lives. "It is as though their aspiration toward abstract supernaturalitruth has ironically brought them around to an abstract natural automatism" (Feidelson, p. 50).

The Scarlet Letter is unique in its social commentary for it presents the weaknesses of the Puritan community as well as pointing out potential problems in the romantic view of complete selfreliance. In this book, Hawthorne looks into the society of the past and finds it lacking. He is extremely critical of the Puritan exaggeration of the importance of $\sin$ and $i$ ts negative attitude toward salvation. It is a stern and joyless society which denies the beauty of nature and the heart. It recognizes no truth but that of the intellect. Characterized by sterility, the Puritan society binds itself to the ideas and practices of the past. The people of the community are cold and unfeeling, but they have built a society which is strong and which is dignified by the moral principles which it enforces.

Stewart points out that "one of the chief thematic tensions in Hawthorne is the tension between the Puritan and romantic tendencies" ("Puritan Humanism," p. 346). The romantic view is in direct opposition to the Puritan philosophy, and Hester, the first of the 
major characters to be discussed, is considered by $\mathbf{S}$ tewart to be "spokesman for the romantic view" ("Puritan Humanism," p. 346). 
Hester Prynne has a particularly close association with nature. She is a beautiful woman whose appearance is the very essence of femininity. There is something quite sensual about her features, her dark, luxuriant hair, and radiant, black eyes.

The young woman was tall, with a figure of perfect elegance, on a large scale. She had dark and abundant hair, so glossy that it threw off the sunshine with a gleam, and a face which besides being beautiful from regularity of feature and richness of complexion, had the impressiveness belonging to a marked brow and deep black eyes. She was lady-like, too, after the manner of the feminine gentility of those days; characterized by a certain state and dignity... and never had Hester Prynne appeared more lady-like .. than as she issued from the prison. Those who had before known her... were astonished and even startled, to perceive how her beauty shown out, and made a halo of the misfortune and ignominy in which she was enveloped. (p. 53)

Similar to that of the forest, Hester's beauty holds a deep mystery of passion and of love, and the Puritan populace is fascinated by her. Her release has "attracted a pretty large number of the inhabitants of Boston; all with their eyes intently fastened on the iron-clamped oaken door"l (p. 49). A school holiday has been declared for the occasion, and a crowd of young schoolboys, eager to understand her crime, scampers around her.

At this point, Hawthorne establishes the passionate nature of Hester's character. The blush on her cheek is a "burning" one, and her rebellious resentment of civil authority is obvious in her actions (p. 52). She refuses to be ushered out of prison by the town beadle and, smiling and facing her judges, she refuses to bow her head in shame. In this opening scene, Hawthorne dramatizes the 
unspoken and undeniable contrast between this beautiful, passionate woman and her stark, stern society. In Feidelson's opinion "she is pitting her 'natural' dignity and force against the abstract dignity and force by which the Puritans attempt to annihilate nature" (Feidelson, p. 53). The society, founded on the concept of sin and supported by the pillars of punishment and law, is confronted with a woman who cannot and will not be restricted by society's strictures. Feidelson states that Hester demonstrates "an affirmative individualism, humanism, and naturalism" which is contrary to all that society teaches (Feidelson, P. 52). To a society steeped in reverence for the past, Hester's very nature is a dangerous challenge. This confrontation scene foreshadows Hester's future philosophical rebellion and also prepares the reader for the forest scene in which Hester openly declares the thoughts and attitudes unspoken on the scaffold. Hawthorne places special emphasis on the conflict between Hester and society by his vivid description of appearances. The townspeople dressed in drab, colorless clothes, wait in a throng outside the prison door. Barely individualized, the Puritan townsmen appear to be little more than shadows. The women, however, are distinguished by a singularly vicious attitude. They are described as hefty, coarse creatures with no semblance of sexuality. Elderly, ugly, and "hard-featured," they are wi thout human sympathy (p. 51 ). They instinctively regard Hester with venomous distrust. Her voluptuous beauty, her obvious fertility, and her individual dignity are qualities which they castigate with a vengeance. It is indeed ironic that "the ferocity of the women in the market place is as lawless and as natural as the lust they denounce, and it 
complements the rigid natural law that dominates their men" (Feidelson, P. 50).

It is significant that two voices of sympathy distinguish themselves from the crowd. A young woman with a child makes a plea for compassion, and a man expresses trust in human virtue. With these two voices, Hawthorne reminds his reader that just as a wild rose will inexplicably persist in the sterile Puritan soil, there is also hope that remnants of brotherly love will be retained in the harsh Puritan atmosphere. The vast majority of voices, however, join to denounce Hester and her lawless passion.

It is the letter A that most effectively expresses Hester's passionate nature. It is done "in fine red cloth, surrounded with an elaborate embroidery and fantastic flourishes of gold thread.... It was artistically done, and with.. much fertility and gorgeous luxuriance of fancy" (p. 53). The combination of the scarlet letter and her drab dress "seemed to express the attitude of her spirit, the desperate recklessness of her mood, by its wild and picturesque peculiarity'l (p. 53). It is also symbolic of the ambivalence of her position. She is at once attempting to express her individuality while remaining a part of her society. The brilliant beauty of the scarlet letter does not correlate with the dullness of the dress. In the same manner, the intensity of Hester's individuality cannot be weakened by membership in society.

The ordeal of standing on the scaffold before her peers is excruciating for a woman of Hester's deep emotional nature. 
It was almost intolerable to be borne. Of an impulsive and passionate nature, she had fortified herself to encounter the stings and venomous stabs of public contumely . . But, under the leaden infliction which it was her doom to endure, she felt, at moments, as if she must needs shriek out with the full power of her lungs, and cast herself from the scaffold down upon the ground, or else go mad at once. (p. 57)

Forced to make a public display of her sin, Hester's reaction is violent and defiant. Public confession, intended to purge the soul and establish harmony wi th society, has the opposite effect on Hester because it is not voluntary. Lewis suggests that in Hawthorne's mind, forced confession "violates some urgent, perhaps some sacred, principle of life."l

From the Puritan point of view, however, Hester's silent rebellion, her unspoken demand for privacy, her refusal to bend under civil law and announce the name of her child's father, all are sinful acts and attitudes which alienate her from the purifying effects of her society. Their code demands that Hester's rehabilitation can come only by "self annihilation before an external public law"' (Feidelson, pp. 51-52).

Hester's emotions, like the forces of nature, are sometimes ungovernable. Her sin of adultery was the result of this lawless passion, and her reaction to the ignominious punishment on the

'R. W. B. Lewis, "The Tactics of Sanctity," Hawthorne Centenary Essays, ed. Roy Harvey Pearce (Columbus: Ohio State University Press, 1964), p. 274. 
scaffold is also fiercely felt. "Hester Prynne was found to be in a state of nervous excitement that demanded constant watchfuiness, lest she should perpetrate violence on herself, or do some halffrenzied mischief to the poor babe" (p. 70). Only a medicine of which Chillingworth had learned from an Indian who knew "many new secrets in the wilderness" could soothe Hester's agitated state (p. 72). While Master Brackett had tried the society's traditional methods of quieting prisoners such as rebuking and threatening further punishment, Hester reacts only to the medicine which nature can provide.

In addition to being a passionate woman, Hester is also characterized as being impulsive and unpredictable. Her emotions govern her actions; she does not plan her course of behavior before She puts it into action. She simply reacts emotionally and deeply. When Hester confronts the Governor and pleads to keep her Pearl, she displays violent emotions. She does and says what she feels, without thinking about the logical consequences.

"God gave me the child!" cried she. "He gave her in requital of all things else, which ye had taken from me. She is my happiness!--She is my torture, none the less!"--And here, by a sudden impulse, she turned to the young clergyman, Mr. Dimmesdale, at whom, up to this moment, she has seemed hardly so much as once to direct her eyes.--"'Speak thou for me!" cried she. "Thou knowest,--for thou hast sympathies which these men lack!-thou knowest what is in my heart, and what are a mother's rights." (p. 83)

Hawthorne further emphasizes her lack of self control by stating that her appeal was "wild" and had provoked her "to little less than madness" (p. 83).

Hester's Madness" is, indeed, a shock to her Puritan elders, 
Mr. Wilson and Governor Bellingham. Her emotions are in full control of her at this point, and her intellect is quite powerless. Hester is certainly not society's product, for she cannot force herself to react to life in a cold, logical manner. Her beauty, her passion and her strength all link her irrevocably with the forces of nature. The men with whom she pleads, however, are so completely allied with the forces of society that they have no comprehension of Hester's emotional state. While she reacts with pure emotion, they, in contrast, are governed completely by their intellect. Reverend Wilson, the oldest of Boston's clergymen, is a great scholar whose "intellectual gifts" have been developed, but his "kind and genial spirit" has never been exercised (p. 65). Governor Bellingham, the Puritan civil authority, proudly ignores the impulsiveness of youth and guides the community by "the sombre sagacity of age" (p. 64). His "elaborate ruff. - caused his head to look not a little like that of John the Baptist in a charger" (p. 108). The point, humorously stated, is that Bellingham's head has been figuratively divorced from his body, and that he is totally lacking in qualities of the heart. Hester, on the other hand, is passionately concerned about the future. Her hope for future salvation lies with Pearl. Wilson and Bellingham, dispassionately guided by the laws of ages past, are apparently unconcerned with the future. Both men are old, and Governor Bellingham persists in dressing in the fashion of King James. The creative urge of these leaders lies stagnant as a result of their reverence for the past. It is fitting, then, that the lifegiving forces of nature would be alien to them. At the scene in 
the market-place, Reverend Wilson finds the bright sunlight too harsh for his eyes which were more accustomed to the dim light of his study. Hawthorne suggests that Wilson resembles an antique portrait of a man rather than a living man because he is so lacking in the vitality of nature.

By contrast, Hester is strongly associated with nature by her creativity. Like nature, Hester is capable of producing new life, and Pearl is the very epitome of life and energy. Hester's creativity is also evidenced by her sewing. Her work is exquisite and imaginative; the scarlet letter on her dress demonstrates her flair. Elaborate and resplendent, it amazes the Puritan townsmen. It is interesting to note that just as Hester's peers are fascinated by her sin, its symbol, and the passion that produced both, they are also dependent upon Hester for her creativity and imagination in sewing. Hester's needlework is, indeed, magnificent enough to be called art. Because no one else in her society was gifted with such artistic creativity, Hester provides handiwork for "public ceremonies, such as ordinations, the installation of magistrates, and all that could give majesty to the forms in which a new government manifested itself to the people" (p. 82).

Hester's most beautiful efforts, however, adorn her child, Pearl. These clothes are created with "a fantastic ingenuity, which served, indeed, to heighten the airy charm that early began to develop itself in the little girl" (p. 82). This sewing is, to Hester, more than simply a means of earning her living. It provides for her a means of venting her emotions, of expressing her love 
and her creative urges.

She had in her nature a rich, voluptuous, Oriental characteristic,--a taste for the gorgeously beautiful, which save in the exquisite productions of her needle, found nothing else, in all the possibilities of her life, to exercise itself upon. -. To Hester Prynne, it might have been a mode of expressing, and therefore soothing, the passion of her life. (p. 83)

The Puritan women who had awaited Hester's release from the prison had been shocked by Hester's mode of creating her scarlet letter simply because it was such an eloquent expression of her spirit. It was a flagrant display of rebellion against her Puritan judges and a silent appeal for the passionate beauty of her love. How apt was the statement of the youngest of the women: "'Not a stitch in that embrofdered letter, but she has felt it in her heart!" (p. 54). True, for whatever her heart felt, her needle expressed. Hester's voluptuous beauty, her creative energy, and her impulsive, passionate character are all the gifts of nature which make her an alien in the stern, dispassionate Puritan society. Her isolation places her in a sphere all of her own. Throughout the rest of her life, her scarlet letter will produce an almost magic circle around her which will not permit penetration by any other human being.

Nevertheless, Hester strives to maintain a fragile and superficial relationship with her society. She remains in Boston, living in a cottage on the outskirts of town rather than in the midst of the colony. ${ }^{2}$ She earns her living by sewing, and in that manner,

${ }^{2}$ Hawthorne has placed Hester symbolically midway between the wilderness of nature and the civilized rigidity of society. It is an apt literary touch in that her character, at this point in the romance, is torn between the forces of nature and society. She is trying 
she vicariously participates in all the ceremonies of society with the single exception of weddings. She becomes a Sister of Mercy.

She was quick to acknowledge her sisterhood with the face of a man, whenever benefits were to be conferred. None so ready as she to give of her little substance to every demand of poverty; even though the bitter-hearted pauper threw back a gibe in requital of the food brought regularly to his door, or the garments wrought for him by the fingers that could have-embroidered a monarch's robe. None so self-devoted as Hester, when pestilence stalked through the town. In all seasons of calamity, indeed, whether general or of individuals, the outcast of society at once found her place. She came, not as a guest, but as a rightful inmate, into the household that was darkened by trouble. (pp. 160-161)

Hester makes no attempt, however, to become accepted by her

peers in the Puritan community. Her relationship to the townspeople is purely superficial. She is allowed to exist along the circumference of the circle of her society, but she is not allowed to enter fully.

In all her intercourse with society, however, there was nothing that made her feel as if she belonged to it. Every gesture, every word, and even the silence of those with whom she came in contact, implied, and often expressed, that she was banished, and as much alone as if she inhabited another sphere, or communicated with the common nature by other organs and senses than the rest of human kind. She stood apart from mortal interests, yet close beside them, like a ghost that revisits the familiar fireside, and can no longer make itself seen or felt; no more smile with the household joy, nor mourn with the kindred sorrow. (p. 84)

The anguish of Hester's isolation produces contradictory results. Outwardly, she appears to accept her punishment with shame and humility. Her behavior implies that she is truly repentant, but her looks belie her emotional state. She remains in the town of Boston and stoically receives all the insults which the townspeople throw her way. 
Hester had schooled herself long and well; she never responded to these attacks, save by a flush of crimson that rose irrepressibly over her pale cheek, and again subsided into the depths of her bosom. She was patient,--a martyr, indeed. (p. 85)

Working hard, she sews what is ordered; she gives much of her earnings to the poor; she helps the sick and suffering, and asks for nothing in return. "She never battled with the public, but submitted uncomplainingly to its worst usage; she made no claim upon it, in requital for what she had suffered" (p. 160).

Because Hester appears humble, the public's attitude is eventually slightly softened in her case. The scarlet letter comes to mean "Able" to many of the townspeople. Waggoner argues that in the eyes of the Puritans, Hester rises from the depths of sin "to a position not too remote from Mr. Wilson' (Waggoner, P. 142). The civil and religious leaders of the Puritan community 'were longer in acknowledging the influence of Hester's good qualities than the people"l (p. 162). Blinded once more by her past sin, they are very reticent to adjust their former opinion. Eventually, however, even they become less critical. Chillingworth announces to her that "it was debated whether or no, with safety to the common weal, yonder scarlet letter might be taken off your bosom" (p. 169).

Hester's demeanor has been irrevocably hardened into marble coldness by society's stigma. Her actions suggest humility and repentance. Her appearance suggests that her passion has been subdued by society's law. 
There seemed to be no longer any thing in Hester's face for Love to dwell upon; nothing in Hester's form, though majestic and statue-like, that Passion would ever dream of clasping in its embrace; nothing in Hester's bosom, to make it ever again the pillow of Affection. Some attribute had departed from her, the permanence of which had been essential to keep her a woman. (p. 163)

Indeed, Hester, like the women who witnessed her public humiliation, appears now to be quite sexless. It seems that her major problem now is "not an external battle against the established order, but an internal struggle to assimilate that order by translating it into her own language" (Feidelson, p. 56). Her sin had been a sin of passion, and Hester struggles frantically to destroy the deep well of emotion within her.

All the light and graceful foliage of her character had been withered up ... and had long ago fallen away. . Even the attractiveness of her person had undergone a similar change. It might be partly owing to the studied austerity of her dress, and partly to the lack of demonstration in her manner. It was a sad transformation, too, that her rich and luxuriant hair had either been cut off, or was so completely hidden by a cap, that not a shining lock of it ever once gushed into the sunshine. (p. 163)

In this passage, Hawthorne's choice of words is particularly important. By making constant references to nature's beauty and luxuriance, the author further emphasizes the vital life force which Hester is trying to smother. He refers to her "light and graceful foliage" and denotes its now "withered" state. He describes Hester's hair as being "rich and luxuriant," and in so doing uses the same adjectives that he has used to describe the forest. Even as Hester struggles to destroy her passionate nature, Hawthorne is careful to remind his reader that Hester is still closely associated with nature's qualities. 
While Hester assumes this marble facade, however, she cannot experience the warmth and joy which the physical universe had previously given to her. The sunshine seems to run away from her. Seeing Pearl playing wi th the sunshine, Hester tries to grasp some of it. "As she attempted to do so, the sunshine vanished," proving that when she denies her physical being in an attempt to achieve an abstract goal of purity, she deadens her ability to commune with the natural universe (p. 184). By contrast, in the forest, when Hester again proclaims her passion and defiance of Puritan rule, the sunshine surrounds and embraces her.

Critics disagree as to the success or failure of Hester's repentance. Herbert Gorman feels that "Hester's guilt is absolved through her public suffering, and her great and noble will and self-command change her very badge of shame into a symbol of a lost world rewon."13 Regis Michaud argues for the opposite extreme. He proclaims that "Hester Prynne has no shame, no remorse for her sin. She is proud of it. $1^{4}$ Feidelson agrees with neither of the above views, but states that "her consciousness becomes the stage of a life-long dialogue between a voice of Puritan negation and the strong voice of that positive freedom which is evinced by the very fact of her lively consciousness" (Feidelson, p. 56).

3 Herbert Gorman, "Absolved, Redeemed, Damned: A Triangle," Arne: A Study in Sol itude (New York: George H. Doran Company, to rpt. in Nathaniel Hawthorne, The Scarlet Letter, ed. Sculley Bradley, Richmond Croom Beatty, and E. Hudson Long (New York: W. W. Norton and Co., 1962), p. 251.

4 Regis Michaud, "Freud and the triangle," The American Novel 
The point to be emphasized here is not the success or failure of Hester's attempt to repent of her sin and to purify her nature; the point is simply that she does make a sincere and honest effort to do so.

Her first step is to alter her appearance. Next she tries to emulate her elders by forcing her mind to dominate her body. She "compelled herself to believe" that her soul would be purged by this earthly punishment (p. 80$)$. She "reasoned" that her martyrdom would result in a saint-like state eventually (p. 80$)$. Hester "struggled to believe that no fellow-mortal was guilty like herself" (p. 87). She does her best to discipline her mind and body according to the Puritan code, but like the forces of nature which are "never subjugated by human law," Hester's nature is never tamed by society's punishment (p. 203).

Though Hester tries to convince herself that she has chosen to remain in Boston because it had been the scene of her guilt and therefore should be the scene of her punishment, the whole truth is that she endures the torture of staying there because of an undying love for Dimmesdale. She deems their love sacred and dreams that they will someday be united.

Over and over again, the tempter of souls had thrust this idea upon Hester's contemplation, and laughed at the passionate

Wy: A Social and Psychological Study, (Boston: Little, Brown, Company, 1928), Pp. 32-45, rpt. Nathaniel Hawthorne, The Scarlet Letter, ed. Sculley Bradley, Richmond Croom Beatty, and E. Hudson Long (New York: W. W. Norton and Co., 1962), p. 256. 
and desperate joy which she seized, and then strove to cast it from her. She barely looked that idea in the face and hastened to bar it in its dungeon. (p. 80)

Even though Hester's current appearance lacks beauty and sex appeal, and though she is struggling to achieve the same effect on her heart that she has on her demeanor, the natural passion of her heart will not be buried. She continues to love Dimmesdale. While she intellectually argues to the contrary, she is forced upon occasion, to acknowledge the truth of her heart. This experience occurs when Dimmesdale looks at her scarlet letter. His glance seems "to give momentary relief, as if half of her agony were shared" (p. 86). In that moment, the intensity of her love returns. Because she has been forbidden the freedom to love Dimmesdale, her guilt at doing so is increased. "The next instant, back it all nushed again, with still a deeper throb of pain; for, in that brief interval, she had sinned anew' (p. 86).

Just as her love refuses to abate, so too does the violence of her despair. Feeling desperately lonely and frustrated by her inability to discipline a child

who had been born amis5,--the effluence of her mother's lawless passion .. . a fearful doubt strove to possess her soul, whether it were not better to send Pearl at once to heaven, and go herself to such futurity as Eternal Justice should provide. (p. 166)

The intensity of such anguish is awesome. Of equal potency is the strength of her hatred. "'Be it sin or no,' said Hester Prynne bitterly.. 'I hate [Chillingworth]... Yes, I hate him!' - Had seven long years, under the torture of the scarlet letter, inflicted so much of misery, and wrought out no repentance?" ( $p$. 176- 
177). Hester is unable to repent of her emotions. After an agonizingly long period of doing battle with these stubborn forces of nature, Hester's love remains intense; her despair is so fierce as to make suicide appear preferable to life; her resentment and hatred toward Chillingworth have not been quelled. To complicate her dilemma further, Hester seems to develop an uncanny ability to perceive hidden $\sin$ in others. As she struggles to control her natural ebullience, to dominate her body with her mind, and to strive toward the purity of her townspeople, this sympathetic sense suggests that "the outward guise of purity was but a lie"l (p. 86). The truth, she perceived, would place a scarlet letter on many breasts. This sympathetic sense is loathsome to her, and though she struggles against it, the reaction is, of course, a loss of faith in the pristine morality of her Puritan peers and judges. She senses the same sin of passion in those with the guise of utmost purity. Again, Hawthorne is attributing to Hester, nature's deep sympathy for passion and love. Just as nature responds to Hester's reaffirmation of sensual joy and love, so too does Hester naturally respond to the same quality in others. Levin feels that in her ability to sense sin, "she becomes innately superior to those fellow citizens who despise her, and whose trespasses are compounded by their hypocrisies. Their social ostracism . . endows her with a 'sympathetic knowledge of the hidden sin in other hearts,' which ultimately leads to a kind 
of redemption. $11^{5}$

Hester does not want to doubt the Puritan ethic. She is making a valiant attempt to harden and subdue her thoughts and emotions into the iron framework of the Puritan way of life. She is schooling Pearl according to the belief of the Puritan religion. In fact, Pearl's religious training had been so concentrated that at three years old, she "could have borne a fair examination in -. the first column of the Westminster Catechism" (pp. 111-112). Hester herself longs for the security and peace of mind found only in the sanctity of the church. The church, however, denies her its solace just as the townspeople had. "If she entered a church, trusting to share the Sabbath smile of the Universal Father, it was often her mishap to find herself the text of the discourse." Even on the street "clergymen paused ... to address words of exhortation" which only add to her torment (p. 85).

While Hester reaches out to the church, grasping for guidance and security, the church elders use her as an example of depravity. Allowing her no help or comfort, they point to her as a "living sermon against $\sin ^{\prime}(p .63)$. They view her sin as particularly frightful because it serves as a reminder of their own naturally sinful state. Hester had been corrupted by the

5 Harry Levin, The Power of Blackness: Hawthorne, Poe and Melville (New York: Alfred A. Knopf, 1958), rpt. in Nathaniel Hawthorne, The Scarlet Letter, ed. Sculley Bradley, Richmond Croom Beatty, and E. Hudson Long (New York: W. W. Norton \& Company, 1962), p. 357. 
forces of nature, according to their way of thinking, and the Puritans wage a perpetual battle against these forces. Therefore, their treatment of her weakness is forever harsh.

That treatment compounds Hester's problem. She has made an attempt to reject her nature and to adopt the Puritan mode of living. When she is denied the strength and solace which the community could afford her, she is plagued by a mind teeming with doubts and questions. She is lost in a "dismal labyrinth of doubt" (p. 99). She has tried to be repelled by the physical universe, but "the shade of the trees and the sun in the flowers seemed to be beautiful to Hester Prynne and to be organically connected with her existence. ${ }^{16}$ She has attempted to control her emotions, but Hester's heart, which again and again overpowers her intellect, will not repent or relent. Then, when Hester begins to doubt the true morality of her society, she has nothing on which to anchor her trust and faith. Eventually, therefore, Hester's thoughts follow the path of her natural passions. This freedom of thought was made possible by her complete isolation from friends and confidants.

She had wandered, wi thout rule or guidance, in a moral wilderness; . . Her intellect and heart had their home, as it were, in desert places, where she roamed as freely

6Larzer Ziff, "The Artist and Puri tanism" Hawthorne Entenary Essays, ed. Roy Harvey Pearce (Columbus: Ohio State University Press, 1964), p. 264. 
as the wild Indian in his woods. For years past she had looked from this estranged point of view at human institutions, and whatever priests or legislators had established; criticizing all with hardly more reverence than the Indian would feel. . . Shame, Despair, Solitude! These had been her teachers,--stern and wild ones,--and they had made her strong, but taught her much amiss. (p. 200)

Hester's freedom of speculation allows her to develop a philosophy which worships the human impulse to love more than it respects society's attempt to control it. After surviving seven years of lonely wretchedness, Hester begins to think about $1 \mathrm{i}$ fe and love in a manner which is quite the opposite of that which her society would expect or appreciate. 'Nothing natural was ugly-this was her special perception" (ziff, p. 264). Actually, the scarlet letter has been a failure for it has not smothered Hester's emotions, and it has not taught her to revere society itself or its laws. Hester states unequivocally to Chillingworth that

it lies not in the pleasure of the magistrates to take off this badge. . . Were I worthy to be quit of it, it would fall away of its own nature, or be transformed into something that should speak a different purport. (p. 169)

She considers civil law as secondary to the law of her love. "She deemed it her crime most to be repented of, that she had ever endured, and reciprocated, the lukewarm grasp of [Chillingworth's] hand, and had suffered the smile of her lips and eyes to mingle and melt into his own" $(p .176)$. Her marriage had been a corruption of pure love, and was, therefore, a crime in Hester's eyes.

Hester's explicit statement of her belief is made in the 
climactic forest scene. Having resolved to tell Dimmesdale the truth about Chillingworth's identity, Hester meets the minister in the wilderness of the woods. In a scene of extreme agony and Joy, Hester whispers 'What we did had a consecration of its own. We said so to each other! Hast thou forgotten it?" (p. 195). It is in this scene that Hester reaffirms her sensual nature and in so doing is once again united with the forces of the physical universe. In a ritual of freedom and joy,

she undid the clasp that fastened the scarlet letter, and, taking it from her bosom, threw it to a distance among the withered leaves... . By another impulse, she took off the formal cap that confined her hair; and down it fell upon her shoulders, dark and rich, with at once a shadow and a light in its abundance, and imparting the charm of softness to her features. There played around her mouth, and beamed out of her eyes, a radiant and tender smile, that seemed gushing from the very heart of womanhood. A crimson flush was glowing on her cheek, that had been long so pale. Her sex, her youth, and the whole richness of her beauty, came back from what men call the irrevocable past, and clustered themselves, wi th her maiden hope, and a happiness before unknown, wi thin the magic circle of this hour. (p. 202)

Feidelson points out that it is significant that "the wilderness around them responds wi th favorable auguries" and the lovers are bathed in sunshine (Feidelson, p. 59). Fogle sees this scene as "an epiphany" of joy and of light." Hester re-establishes her close association with nature and joyfully discards the Puritan law. The restrictions of society are too confining for the ebullience of her heart, and Hester revels in her new freedom. It is

7Richard Harter Fogle, Hawthorne's Imagery: The "Proper Minht and Shadow' in the Major Romances (Norman: University of thahoma Press, 1969), p. 40. Hereafter cited as Imagery in the text. 
the lawless freedom of untamed nature which the lovers enjoy for a brief hour.

It is important to note that again Hawthorne's description of Hester draws a direct correlation between her and the natural universe around her. As the sunshine envelops the lovers, Hester's eyes "beam" and her hair reflects the sun's rays with an abundant light. Her smile is "radiant" and her cheeks are "glowing." The "flood of sunshine" with which nature blesses, this reunion is almost equalled by the sunshine emanating from Hester's physical being. Although the sunshine had fled from her when she had had a Puritan appearance, she not only grasps it in this scene, she appears to be part of it.

Hester's emotions once again cloud her intellectual powers as she impulsively urges Dimmesdale to run away with her and find freedom in a foreign land. In Male's view

never--not even in the exhortations of Emerson and Thoreau-has the vision of dawn, the promise of America, the dream of a second chance found more deeply felt utterance than in her appeal, as she urges the time-drenched man to recover himself, to put on a new name and leave the ruin behind him. (Male, p. III)

Hester fails to recognize that her philosophy of love is in direct opposition to that of Dimmesdale. While to her, physical passion is a direct expression of love which is quite sacred and beautiful, to Dimmesdale it is proof of man's corrupt nature. While Hester envisions love as a bond which will unite the lovers after death, Dimmesdale is much more pessimistic and concentrates on the power of $\sin$ rather than the strength of love. Seymour Gross states 
that

her "impulsive and passionate nature" is neither romantically exalted nor moralistically condemned: it is simply presented as tragic because it was its fate to intersect with Dimmesdale's equally passionate desire for renunciation. . . Hester cannot go into Dimmesdale's world, where both might find peace of soul in an orthodox submission to the Calvinistic God; and he cannot come into hers, where both might find joy in a free submission to human love. ${ }^{8}$

After separating and returning to society, the two lovers re-enter their own different worlds, never to approach such unity again. Hester assumes her iron facade once more, but there is no attempt, this time, for repentance. She has fully embraced an antinomian view of life. Her new philosophy frees her from all laws and regulations accepted and enforced by her society. Instead, Hester is guided by her firm faith and her individual trust in God's grace. She sees her stoic appearance as a temporary guise only. Her emotions dominating her thought, Hester does not grasp the reality of her situation until she sees her lover "so unattainable in his worldly position" march past her in the procession (p. 239). Then the unhappy realization of their differing philosophies strikes her. Her first reaction upon seeing Dimmesdale is, of course, emotional. More slowly, the intellectual understanding develops in her mind. 'Her spirit sank with the idea that all must have been a delusion, and that, vividly as she had dreamed it,

\section{BSeymour L. Gross, "Solitude, and Love, and Anguish: The} Tragic Design of The Scarlet Letter," CLA Journal, III (March 1960) Pp. 154-165, rpt. in Nathaniel Hawthorne, The Scarlet Letter, ed. Sculley Bradley, Richmond Croom Beatty, and E. Hudson Long (New York: W. W. Norton \& Company, 1962, p. 362. 
there could be no real bond betwixt the clergyman and herself" (pp. 239-240). Then Hester's emotions take over once again, and she is angered by Dimmesdale's ability to forget their meeting in the forest and to wi thdraw so completely from her world back into his own.

More alone than ever, Hester stands outside the meeting house listening to the sermon which her lover is presenting. Hester is deeply affected by Dimmesdale's sermon, al though she cannot understand its words. She hears only the passion and pathos of Dimmesdale's voice.

Muffled as the sound was by its passage through the churchwalls, Hester Prynne listened with such intentness, and sympathized so intimately, that the sermon had throughout a meaning for her, entirely apart from its indistinguishable words. (p. 243)

Hawthorne has masterfully pictured Hester's plight in this scene. So alienated is she from the Puritan philosophy and religion that she has little or no comprehension of its concepts. So accustomed is she to reacting emotionally to the world around her, that only the varied tones of Dimmesdale's voice which was rich wi th anguish, have meanings for her.

Even after the sermon is over, mindless of the impossibility of their escape, Hester stubbornly clings to her dream of an antinomian life. Dimmesdale is forced to ask her three times to come to him and to help him ascend the steps of the scaffold. "Though it is Hester's strength that Dimmesdale asks for in his ascent to the public confessional, though it is in her arms that he dies, both pursue their separate destinies to the 
end" (Gross, P. 366). When Dimmesdale suggests that such a public confession, which will serve to reunite him with his community, is superior to the dream of freedom they had had in the forest, Hester cannot agree. "I know not! I know not! . . Better? Yes; so we may both die, and little Pearl die with us!" (p. 254). Hester's fierce passion has not abated, and she is as capable here of taking her own life as she was in the prison when Chillingworth had been summoned to sooth her. She stubbornly clings to her dream of an everlasting love uniting her with Dimmesdale for eternity. Male points out that "even her last hope--for a specific reunion in an afterlife--is clothed in earthly terms" (Male, p. 115). So irrevocably has her isolation separated her from the Puritan community with which Dimmesdale longs to be reunited that she but dimly understands her lover's plight. Even Dimmesdale's confession does not serve to reconcile Hester wi th her community as it does Pearl. Stewart states that "Hester, romantic heretic to the last, remained unconvinced, impenitent, unredeemed" ("Puritan Humanism," p. 349).

While Hester views her love to Dimmesdale as pure and eternal, Hawthorne is careful to remind his readers, through Hester's unhappiness, that "a passionate life of the senses is good so long as its satisfactions are a link between carnal and spiritual life. 19 By often associating Hester with the evil aspect of nature, the Black Man, Hawthorne emphasizes the idea that abandonment of one-

9Darrel Abel, "The Theme of Isolation in Hawthorne," Personalist, XXXII, Pt. II (Spring 1951), P. 184. 
self to the lawless immorality of nature can serve to separate a person from the spiritual strength of a community. Hester's first real temptation to the lawlessness of nature occurs before the action of the book begins when Pearl is actually conceived. Of this union, Hawthorne tells his reader nothing, but Hester refers to it twice. To Dimmesdale, Hester says that their love had had a consecration of its own. Ziff has interpreted that consecration as resulting "from the Harmony it formed wi the whole natural world" (ziff, p. 264). Hester had followed her natural instincts and had therefore not denied her deep sympathy wi th the creative forces of the natural universe. To Pearl, Hester admits that "once in my life I met the Black Man! . . This scarlet letter is his mark" (p. 185). In these two speeches, Hawthorne presents nature's greatest gift and greatest evil. It is important to note also that the Black Man's mark has served to sever Hester from the spiritual guidance of the community, thereby rendering Hester even more susceptible to further temptation and moral lawlessness.

Hester's second temptation occurs when the town magistrates are considering taking Pearl away from her. Hawthorne's purpose in the scene is to illustrate Pearl's function in maintaining Hester's association, tenuous though it may be, with her Puritan community. Invited by Mistress Hibbins to Join the Black Man and his happy group in the forest, Hester declines, stating that she "must tarry at home and keep watch over my little Pearl" (p. 117). Had Hester's petition been denied, however, her tenuous 
link with the community would have been permanently severed, and she "would willingly have gone (with thee) into the forest, and signed... the Black Man's book" (p. 117).

Although this scene ends with Hester precariously poised midway between the promised joy of nature and the strict moral code of the Puritan community, Hawthorne is quick to point out that Hester will be continually tempted to follow her natural inclinations and to dedicate herself to sensual pleasures and passions as symbolized by the forest. Mistress Hibbins promises "we shall have thee there anon," thus indicating Hester's continued struggle to reconcile these two forces in her life (p. 117). Nathaniel Hawthorne has so explicitly associated Hester's appearance, personality, and philosophy with the characteristics of nature, that many critics including Stewart, see Hester as a representative of the romantic view of life ("Puritan Humanism," p. 347). This interpretation is further supported by Hawthorne's use of natural symbols in connection with Hester's character. Waggoner has suggested that a "frequent association is set up between Hester and normal flowers" (Waggoner, p. 133). From the very first scene, Hester's love is equated with the wild red rose blooming outside the prison door. Though the strict sterile Puritan air has almost destroyed both the love and the flower, both natural forces persist and bloom. The wildflower is suggestive of natural passion and freedom, and Hawthorne portrays the relationship between Hester's scarlet letter, her acceptance of unrestricted love, and flowers growing naturally in the soil. 
Pearl picks handfuls of flowers and flings them "one by one at her mother's bosom ... almost invariably hitting the mark, and covering the mother's breast with hurts for which she could find no balm in this world" (p. 97). Hawthorne's affinity for connecting two seemingly contradictory ideas can be seen in this scene. The wildflowers with their symbolic connotations are lovely and inviting. One finds joy in their beauty and fragrance. To Hester, however, they bring "unutterable pain" (p. 97). No one has been hurt more or is still more vulnerable to their deceptive beauty.

Hawthorne presents the duality of nature by associating Hester's scarlet letter wi th burrs as well as wildflowers. Again, Pearl serves as the agent, and "taking a handful of these, she arranged them along the lines of the scarlet letter... to which the burrs, as their nature was, tenaciously adhered" (p. 134). They are sharp and painful. They are also almost impossible to discard for they easily imbed themselves in any soft surface. Hawthorne has connected Hester's heart and its emblem of shame, with a nature which is both beautiful and ugly. It is soothing as well as painful. It is both inviting and dangerous. "So Hester walks her ambiguous way between burdock and rose neither of which is alone sufficient to define her nature and her position" (Waggoner, p. 133). The freedom of the wilderness which had always attracted Hester, hurts her also. It offers loneliness and a lack of spiritual support as well as freedom. After Dimmesdale's death, Hester leaves the Puritan settlement and, in so doing, tries to 
establish her individuality and philosophy in an atmosphere of freedom. Waggoner states that Hester "had been literally forced into practicing Emerson's greatest virtue, self-reliance," and she learns that one cannot live a life of absolute independence (Waggoner, P. 140). Lewis feels that

Hawthorne ... obviously sympathized with what he nevertheless regarded as an impossible enterprise-- the effort to escape. - He could share some part of the hope motivating the flight; he could always see beyond the hope to the inevitable return. 10

Once Hester accepts her interdependence with her fellow man, she returns again to the Puritan soil and voluntarily dons the scarlet letter. She immediately establishes an honest relationship with her society. Because she has not been forced to wear the emblem, "the scarlet letter ceased to be a stigma which attracted the world's scorn and bitterness"' (p. 263). This time the scarlet letter seems to bind Hester with her society, for it is "looked upon with awe, yet with reverence too" (p. 263). Hester is still intimately concerned with the problems of love and the heart, but she is no longer defiant of the community. Instead, working within its framework, she looks forward to a time when society will "establish the whole relation between man and woman on a surer ground of mutual happiness" (p. 263). Clough feels that Hester escapes tragedy by "merging once more into the human stream, with all its imperfections" (Clough, p. 120). It is true that Hester grows in strength and stature as a result of her suffering, but it is

$$
{ }^{10} \text { Lewis, The American Adam, p. } 116 .
$$


most significant that she develops an awareness of social responsibility which binds her to the community of mankind. In the character of Hester Prynne, Hawthorne demonstrates that man is dependent on both the physical universe and the society around him. He cannot disregard either one completely, but he 'must guard against the anarchy which results from placing personal impulse above socially regulated behavior'l (Ziff, p. 264). Hawthorne's answer, like Hester's, is that a harmonious life will cone not by violating society's laws, but by combining society's moral strength and nature's natural joy. 
of all the characters in The Scarlet Letter, Arthur Dimmesdale is the one most capable of achleving a balance between the head and the heart. He is depicted by Hawthorne as being gifted with great intellect and deep sensitivity. He is"wise beyond his years" and has distinguished himself in his religious studies at "one of the great English universities" (p. 65). He is an extremely erudite and pious man. His intellectual assets are, however, balanced by a deep emotional nature. Chillingworth's study of Dimmesdale's character shows him to have "high aspirations for the welfare of his race, warm love of souls, pure sentiments, natural piety, strengthened by thought and study, and illuminated by revelation" (p. 130). Chillingworth discovers the other side of Dimmesdale's nature, however, when he uncovers the "hot passion" of Dimmesdale's heart (p. 137).

As a result of Dimmesdale's scholarly attainments, he is placed in a position of importance in his society. He is a respected teacher and leader of the townspeople, and he feels a responsibility for the protection and redemption of his parishioners' souls. In addition, he is given the awesome responsibility of interpreting and enforcing God's law. His position demands a degree of isolation from his fellow man, for Dimmesdale must stand apart from the townspeople in order to see his society objectively. He must be a member of the society while, at the same time, he must be superior to it in order to judge it and lead it well. The result of this arrangement is that Dimmesdale 
"could only be at ease in some seclusion of his own" (p, 66). Therefore, while his intellectual gifts provide Dimmesdale with an important position in his society, they also serve to isolate him from the society by placing him above his peers.

It is Dimnesdale's passionate nature, however, that provides him with his outstanding ability to teach and lead his parishioners. His emotions are expressed by his voice which is "sweet, rich, deep, and broken" (p. 67). It is Dimmesdale's voice which affects his listeners more than the intellectual message of his words. His voice, similar to an organ, produces tones which "breathed passion and pathos and emotions high and tender, in a tongue native to the human heart, wherever educated" (p. 243). His voice, affecting the audience emotionally, connects the "listeners into one accord of sympathy" (p. 67). It is this emotional strength that the other Puritan leaders lack, and which makes Dimmesdale especially effective and powerful. He alone recognizes the cruelty in forcing Hester to "lay open her heart's secrets in .. broad daylignt" (p.65). It is true that Dimmesdale is afraid that Hester will be forced to acknowledge his sin as well as her own, and so he has a double reason for avoiding the duty of questioning her. He objects to the entire procedure in order to protect himself and because he does not approve of forcing an individual into a confession. He explains to Chillingworth,

There can be . . no power short of the Divine mercy, to disclose... the secrets that may be buried with a human heart. The heart, making itself gullty of such secrets, must perforce hold them, until the day when all hidden things shall be revealed. (p. 131) 
Dimmesdale differs from the other Puritan leaders in that he alone has reverence for the "sanctity of the human heart" (p. 195).

I ronically it is Dimmesdale's emotional nature which enables him to achieve greatness in the pulpit and which also causes him to become painfully isolated from the society which reveres him. He commits a sin of passion with Hester and, as a result, experiences an overpowering sense of guilt. Clough suggests that "the sense of guilt inevitably brings with it a sense of isolation from what one believes he has sinned against" (Clough, p. 10). In committing adultery, Dimmesdale has sinned against God, and because God's laws are also the laws of the Puritan society, Dimmesdale has sinned against his society. He feels doubly estranged from his God and from his fellow man. Dimmesdale compounds his crime by adding hypocrisy to sin. He does not willingly submit himself to public confession which $\mathrm{Hall}$ contends is "the saving ethic of the society" (Hall, P. 172). Dimmesdale rejects this honest relationship with his society and thereby forfeits "his link with the common humanity by denying not his deed, which is human, but love, paternity, the human bond that might have saved $\mathrm{him}^{\prime \prime}$ (Clough, P. 124). Hall suggests that "to evade an original and proper relationship toward men, as Dimmesdale did, is to bring upon your head all the punitive force of morality with none of its regenerative faculties" (Hall, P. 172). Dimmesdale suffers physically and emotionally as a result of his sin and consequent estrangement. Tormented as he is with his own sense of guilt, however, 
Dimmesdale is more able to understand and sympathize with the sins of common humanity. His serious sermons are rich with emotion and convey the anguish "of suffering humanity" which he shares (p. 243). Charles Walcutt points out that "neither the minister's suffering nor his persuasive eloquence come from spiritual heights. They are from the depths."1 As a result, Dimmesdale is gifted with the ability to stir his congregation wi th a power which is awesome.

The Reverend Mr. Dimmesdale had achieved a brilliant popularity in his sacred office. He won it, indeed, in great part, by his sorrows. His intellectual gifts, his moral perceptions, his power of experiencing and communicating emotion, were kept in a state of preternatural activity by the prick and anguish of his daily life. His fame, though still in its upward slope, al ready overshadowed the soberer reputations of his fellow-clergymen. (p. 141)

The other clergymen having developed their minds and neglected their hearts, have no sympathy with mankind. They view humanity as fallen and corrupt and consequently adopt an attitude of condescension when addressing the townspeople. Their voices come down "afar and indistinctly, from the upper heights where they habitually dwell" (p. 142). They lack the ability to touch the human heart. Dimmesdale would have allied with these clergymen had his suffering not provided him with the "Tongue of Flame" (p. 142). Dlmmesdale's sense of $\sin$

kept him down, on a level with the lowest; him, the man of ethereal attributes, whose voice the angels might else have listened to and answered!

\section{'Charles Child Walcutt, "The Scarlet Letter and Its} Modern Critics," Twentieth Century Intrepretations of The Scarlet Letter," ed. John C. Gerber (Englewood Cliffs: Prentice-Hall, 1968), p. 81 . 
But this very burden it was, that gave him sympathies so intimate with the sinful brotherhood of mankind;

so that his heart vibrated in unison with theirs, and received their pain through a thousand other hearts, in sad, persuasive eloquence. (p. 142)

Feidelson points out that 'Dimmesdale's 'Tongue of Flame' is energized by the earthly passion that his Puritanical self despises" (Feidelson, p. 65).

Dimmesdale views his passionate nature with loathing. In full agreement with the Puritan ethic regarding sin and sex, Dimmesdale considers his deep emotional nature as a sign of corruption and the source of his sin. Therefore, he struggles, as does Hester for the seven years following her public shame, to stifle his natural passions and to live strictly within the realm of the mind. Edward Davidson suggests that the "first true stage in Dimmesdale's downfall comes when the minister convinces himself that the body and soul are separate not merely as differing expressions of life, but absolute distinctions of the human being. ${ }^{2}$ The minister attempts to negate his physical being by transcending it and moving into the realm of the intellect. He tries to reject entirely the physical universe around him and to concentrate only on his religious philosophy and his knowledge. In this manner he attempts to purify his soul and repent of his sins. He is, however, unsuccessful for he, more than most men, is gifted wi th "strange sympathy betwixt

2Edward Davidson, "Dimmesdale's Fall," Twentieth Century Interpretations of "The Scarlet Letter," ed. John C. Gerber (Englewood Cliffs: Prentice-Hal1, 1968), P. 83. 
the soul and body" (p. 138). He cannot deny one and allow the other exclusive domination over his being. In an extreme effort to do so, he resorts to violent measures of punishment.

Striving in vain to deny his physical passions and desires, Dimmesdale forces his body to endure fasts and vigils and even bloody beatings. These practices, however, prove unsuccessful, for they "could not purify" his body of its physical desires (p. 145). It is interesting to note that Dimmesdale's overt masochism could be interpreted as a perverted form of his original passionate nature. Instead of denying them, Dimmesdale alters the means of expressing his passions. He provides an outlet for his teeming emotions by applying his bloody scourge. "Oftentimes, this Protestant and Puritan divine had plied it on his own shoulders; laughing bitterly at himself the while, and smiting so much the more pitilessly, because of that bitter laugh" (p. 144). Male points out that "so long as they are covert, the minister's gestures are but a mockery of penitence and his cloistral flagellations, fasts, and vigils are unavailing" (Male, P. 108).

Aware of his failure, Dimmesdale divorces himself more and more from the strength and regenerative forces of nature. His health fails, and he grows thin and weak. 'His form grew emaciated; his voice, though still rich and sweet, had a certain melancholy prophecy of decay in it; he was often observed, on any slight alarm or other sudden accident, to put his hand over his heart, with first a flush and then a paleness, indicative of pain" (p. 120). 
Hawthorne does not equate any natural images wi th Dimmesdale's character. He shuns the sunshine and flowers of nature and even doubts that "grass would ever grow on" his grave (p. 143). Instead, Hawthorne connects the symbols of Puritan society with Dimmesdale's character. Dimmesdale's study overlooks the graveyard which suggest the sterllity of his faith. His twalls were hung round with tapestry, said to be from Gobelin looms, and, at all events, representing the Scriptural story of David and Bathsheba, and Nathan the Prophet" (p. 126). Thus Dimmesdale is constantly reminded of sin. His library is "rich with parchment-bound follos of the Fathers, and the lore of Rabbis, and monkish erudition, of which the Protestant divines -. were .. constrained often to avail themselves" (p. 126).

These books, like those in the Governor's mansion, look back at the beliefs of the past and virtually ignore the future. They provide an escape from the present by leading directly into the past. Strauch points out that the years of punishment had had opposite effects on Hester and Dimmesdale. "Dimmesdale retreated into the past; and Hester ran away into the future. 13 Hawthorne emphasizes this tendency of Dimmesdale's by depicting a scene in the minister's study which contrasts the world of nature and the sphere in which Dimmesdale lives. At noon, when the sunshine is the warmest and brightest, Dimmesdale is confined in his dim study with "a work of vast ability in some somniferous school of literature" (p. 138). The contrast is clear. 
While the physical universe invites creativity and renewed strength, Dimmesdale's intellectual and religious pursuits serve to weaken him physically. They cut him off from the vitality of nature and deny him the strength and support which the forces of nature can provide. Fogle points out that Dimmesdale is always "the man of shadow and concealment... He avoids the light" (Imagery, p. 30).

Eventualiy, Dimmesdale becomes almost imprisoned by

his Puritanical views.

His mind. . impelled itself powerfully along the track of creed, and wore its passage continually deeper with the lapse of time. In no state of society would he have been what is called a man of liberal views, it would always be essential to his peace to feel the pressure of a faith about him, supporting, while it confined him within its i ron framework. (p. 123)

He is dependent on the religion of his society for support and reassurance. When Chillingworth confronts Dimmesdale with new Ideas and views which are alien to the Puritan faith,

it was as if a window were thrown open, admitting a freer atmosphere into the close and stifled study, where his life was wasting itself away, amid lamp-light, or obstructed day-beams, and the musty fragrance, be it sensual or moral, that exhales from books. (p. 123)

Dimmesdale cannot reconcile origional ideas with his own Puritan views. New ideas, like the forces of nature, are "too fresh and chill" (p. 123). Hawthorne has clearly presented Dimmesdale's dependence on his society and his inablility to live comfortably with fresh and alien views. It is, therefore, consistent with his character that he should be shaken by Hester's views on 
law and love when he meets with her in the forest. He is at once invigorated and frightened by them, and he returns to the community in an extremely confused state.

\section{While Dimmesdale cuts himself off from the physical} universe and attempts to purify his soul of his physical passions, Hawthorne makes it clear to the reader that the pious minister is under constant temptation. Mistress Hibbins, with her knowledge of the Black Man, is often connected with Dimmesdale's actions. When he shrieks from the scaffold at midnight, she immediately responds. When Dimmesdale returns from his meeting with Hester in the forest, Mistress Hibbins immediately confronts him and suggests that the next time he goes into the forest, she accompany him. In this manner, Hawthorne indicated that Dimmesdale is and will be continually plagued by the temptations of his natural impulses. Edward Wagenknecht suggests that "the inward festering of the minister's suppressed desires" constantly trouble and tempt him. When the virgins of his church grow pale and tremble in his presence, it is a different passion than that which they recognize and acknowledge that moves them." ${ }^{4}$ The minister, often in the company of such innocent parishioners, is no doubt painfully aware of their passionate emotions and is consequently reminded of his failure to control his own.

In the forest, when Dimmesdale is suddenly confronted by

4Edward Wagenknecht, Nathanial Hawthorne: Man and Writer (New York: Oxford University Press, 1961), P. 141. 
Hester Prynne, the minister asks "Is it thou? Art thou in life?" (p. 189). Hawthorne suggests that Dimmesdale's "pathway through life was haunted thus, by a spectre that had stolen out from among his thoughts" (p. 189). It is clear that the spectre which haunts his thoughts is Hester, and when she suddenly appears before him in the forest, he is not certain whether she is real or imaginary. No doubt she haunts his thoughts because he has not been able to rld himself of the passion he once felt for her. He admits to her in the forest that he has punished himself for his weakness. "In accordance with the Puritan paradox, he would convert his flesh to spirit by dwelling upon the total disparity of his 'sinful' natural body and his intelligent mind" (Feidelson, p. 64). Yet all his efforts have failed. Dimmesdale, tormented by his inability to purge his soul of his corrupt physical body, cries "of penance I have had enough! Of penitence there has been none!"

Dimmesdale's "subjective correlative to the prison-world of Boston is a 'constant introspection' by which he seeks to keep his sin in sight and thereby to rise above it" (Feidelson, P. 64). Dimmesdale is hardly given the opportunity to forget his sin. The tapestries on the walls of his study remind him of his own adultery. He often sees Hester and Pearl and is alarmed that his own "features were partly repeated in her face, and so strikingly that the world might see them!" (p. 206). In addition, Chillingworth takes delight in reminding the minister of his sin. Nevertheless, Dimmesdale cannot purify himself. He announces to Hester that if he had 
successfully purged himself of his corrupt passions, he "would long ago have thrown off these garments of mock holiness" (p. 192).

Nor is Dimmesdale strong enough to admit his love for Hester and his relationship to Pearl. Thus he denies his true identity and, as Newton Arvin contends, "deepens his original wrongdoing" by his inability to admit his guilt. ${ }^{5}$ Weakly and hypocritically, he stands before the townspeople in the guise of purity and solemnity, and the people revere and worship him. They view him as a "miracle of holiness. They fancied him the mouthpiece of heaven's messages of wisdom and rebuke, and love" (p. 142). Yet the disparity between what he appears to be and what he is causes the minister terrible anguish. "It is inconceivable, the agony with which this public veneration tortured him" (p. 143). Intellectually, Dimmesdale always seeks the truth and despises lies, but morally he is too weak to confess the entire truth to his congregation, and consequently he is forced to live a lie. Several times Dimmesdale rises to the pulpit determined to announce the truth to the entire community, but each time he deserves Pearl's reproach "thou wast not bold! Thou wast not true!" (p. 157). Each time Dimmesdale tells only half the truth, and as a result the parishioners idolize him all the more. 'Not being the pure spirit that his congregation think they see and hear, and not having shown himself in the guise of a worthless sinner, he conceives himself to be nothing at all" (Feidelson, p. 66).

${ }^{5}$ Newton Arvin, Hawthorne (New York: Russell and Russell, 1961), p. 189. 
Several critics suggest that his false relationship to

the society causes Dimmesdale more anguish than the acknowledgment of his sin. Hall contends that

it is not the consciousness of sin and guilt that fills the world of Dimmesdale with its trance-like terror; it is the sense of the growing rift between him and society, the feeling that he has somehow become detached from iife and is falling into a moral limbo farther and farther from reality and the honest existence of men. (Hall, p. 171)

Woodberry agrees with this analysis stating that the "minister is not punished as a lover, but as the hypocrite that he becomes. -. [He] suffers from hypocrisy, cowardice, desertion--and self knowledge. ${ }^{16}$ Dimmesdale himself states that he is tortured by his parishioners who look to him for the truth, while he provides them only with the falsehood of his own life. There is no doubt that Dimmesdale is tormented by his $\sin$ of adultery, but his hypocritical relationship to the society also causes him excessive pain. Dimmesdale announces to Hester than if he had just one person with whom he could be completely honest, "even thus much of truth would save me!" (p. 192). He believes that his honesty would provide him with the strength to repent of his original sin.

Dimmesdale has just three such periods of momentary truth. The first of these occurs on the scaffold at midnight in early May. It is Ironic that the minister chooses the darkest hour of night for his confession. He calculates to himself that he will be

Woodberry, pp. 193-194. 
truthful when there is "no peril of discovery" (p. 147). His attempts at confession are extremely feeble, and the minister cries out some unintelligible note which, to his ears, "went pealing through the night, and was beaten back from one house to another, and reverberated from the hills in the background" (p. 148). Although Mistress Hibbins and Governor Bellingham hear Dimmesdale's cry, neither responds actively to the noise which, in actuality, was not as loud as Dimmesdale had imagined. It is interesting to note that Hawthorne chooses these two characters to hear Dimmesdale's cry, for Mistress Hibbins represents to the minister the potential evil in the physical universe, while the Governor is the representative of the sanctity of the Puritan society. Dimmesdale is drawn to both extremes. His passionate nature responds to the physical world around him, while his intellect strives toward the purity which the society attempts to achieve. When Reverend Wilson passes the scaffold, Dimmesdale imagines that he calls to the old man, but is again relieved at being undetected. Male suggests that the "magnificent scaffold scene dramatizes the various degrees of moral blindness in the community and throws the falsity of the minister's rationalizations into sharp relief'l (Male, p. 108)

Later, however, when Pearl and Hester discover him and stand with him on the scaffold, the minister is momentarily revitalized and refreshed. When he takes Pearl's hand, her energy and vitality, which are much like the forces of nature, rush into his weak, chilled body. By taking Pearl's hand and thus acknow- 
ledging his relationship to his child and his lover, Dimmesdale becomes a link in "an electric chain" which not only supports him, but also binds him to other humans (p. 153). Feidelson points out that "these three members of an adulterous triangle commune more profoundly in their dissociation... than do any of the spokesmen of society" (Feidelson, p. 55).

Pearl challenges the minister; "take my hand, and mother's hand tomorrow noontide," but the minister declines, preferring the secrecy of darkness to the honesty of the sunshine (p. 153). Hawthorne has consistently characterized the minister as a man who avoids the warmth of the sunshine. He is a very pale man who walks "in the shadowy by-paths" of life (p. 66). Although friends arrange for him to live in an apartment which will provide a "sunny exposure" for him, the window is covered wi th "heavy window-curtains to create a noontide shadow" $(p, 126)$. Even the sunshine filtered through a window pane seems to be too potent for the minister. Dimmesdale's name further suggests his affinity for darkness. Waggoner states that "his last name falls naturally into two parts, With the root of the first part, 'dim,' suggesting both weakness and darkness" (Waggoner, p. 139). This is especially meaningful when we recall the significance of sunshine in Hawthorne's fiction. 7 Waggoner goes on to point out that the second part of the last name suggest "valley, the heart of which Hawthorne is so frequently reminded by any hollow, opening or cavi ty" (Waggoner, p. 139).

${ }^{7}$ See Chapter 1, pp. 8-9. 
It is also true, that the word "dale" is associated with the world of nature rather than the idea of society.

It is very appropriate, therefore, that the second period of honesty for the minister occurs in the dim seclusion of the forest. Hester has arranged the meeting in order to disclose the truth about Chillingworth, and when she does, the minister shows the powerful passion which he had unsuccessfully attempted to destroy. He looks at Hester 'with all that violence of passion, which--intermixed, in more shapes than one, with his higher, purer, softer qualities--was, in fact, the portion of him which the Devil claimed, and through which he sought to win the rest" (p. 194). Hawthorne has pointed out that the passion which Dimmesdale is capable of has many shapes. In the forest he displays his anger, but at an earlier time he had also been overcome by a passionate love. Hawthorne emphasizes that "the breach which guilt has once made into the human soul is never, in this human state, repaired" (pp. 200-201). Although Dimmesdale has intellectually fortified himself with constant reminders of his weakness and with the iron regulations of his religion, he is still vulnerable to the love he has felt for Hester. He is, as Stewart states, both "the slave of passion and the servant of the Lord" ("Puritan Humanism," p. 349).

At first Hester tries to soothe Dimmesdale's sensitive nature by suggesting that his penitence is "sealed and witnessed by good works" (p. 191). She suggests that he should find comfort and fulfillment in the adoration which the people 
have for him. She does not realize that such adoration is a source of his suffering. Male analyzes this scene by stating that it is "perfectly and ironically balanced, for as the minister is struggling toward outsight and disclosure, Hester is seeking in-sight and utterance. Her moral predicament during the past few years has been just the reverse of his" (Male, p. 109). Thus the two lovers can reaffirm their love, but they no longer view life from the same vantage point. She sees their problem from an antinomian viewpoint while Dimmesdale assesses their thoughts and actions according to the principles and regulations of the Puritan theocracy. Hester earnestly urges Dimmesdale to run away from his society. She does not see that he has anything in common with the "iron men" of the community, and she states that such men have kept the minister's "better part in bondage too long al ready" (p. 197). By "better part" Hester means Dimmesdale's deep emotional nature. She believes that his love and passion are natural and are therefore good. He, on the other hand, sees his passion as the "weaker part" of his character. To him, it is the "eneray" which tries to force its way into the "ci tadel" of Dimmesdale's heart (p. 201).

When Hester urges Dimmesdale to "begin all anew," and to leave his sin and torment behind him, she does not realize his need to confess (p. 198). Feidelson points out that "by sparing him the isolation inflicted on her, by trying to preserve intact his individual dignity and freedom, she has actually isolated him completely" (Feidelson, p. 67). 
It would be foolish to assume that Hester's intellectual arguments convince the minister that individual freedom is more beneficial than society's law. Dimmesdale's intellect is too acute to be so easily persuaded, and therefore when he decides that he can "no longer live without her companionship," he is convinced by his physical exhaustion and love for Hester rather than her reasoning ( $p .201)$. Dimmesdale concludes that he needs her power to sustain him and her tenderness to soothe him. It is significant that Dimmesdale must rely on Hester for strength and for hope for the future. She is akin to the forces of nature in that she provides life-giving qualities to the man weakened by society's sterile attitudes. It is also important to note that Dimmesdale's decision is "conceived by him as a pact with the devil" (Feidelson, p. 68). He considers himself "i rrevocably doomed" because he has "yielded himself with deliberate choice... to what he knew was deadly $\sin ^{\prime \prime}$ (pp. 201, 222).

When Dimmesdale discards society's restrictions and reaffirms his acceptance of his physical emotions and needs, nature responds with a burst of sunshine. The strength and warmth of the physical universe and infused into his pale and emaciated system, and Dimmesdale is revitalized by "breathing the wild, free atmosphere of an unredeemed, unchristianized, lawless region" (p. 201).

There is no doubt that Dimmesdale changes as a result of this forest experience, but critics disagree on the nature of his transformation. Michaud argues that

once freed from repression and anxiety, Dimmesdale reveals him self to be a new man, a man in the full sense of the word 
for the first time, and now he cares neither for his fears nor for Chillingworth who has exploited them. ${ }^{8}$

Male agrees in part with this analysis, and he states that Dimmesdale

has stripped away the old words; he has discarded his old self amid the decaying leaves... The scales have dropped from his eyes; he has attained an Emersonian vision. . . On one hand, he is closer to the freedom of individual growth, less hampered by the principles and prejudices of the social system; on the other, he is . . more deeply involved in a moral wilderness. (Male, p. 113)

Dimmesdale is physically affected by the potent forces of nature, and his passionate feelings which he had so long tried to destroy, are reawakened. Frederick Crews argues that Dimmesdale's joy

is that of his victorious sexuality... He has been blessed with a new energy of body and will. The source of this energy is obviously his libido; he has become physically strong to the degree that he has ceased directing his passion against himself and has attached it to his thoughts of Hester.?

For the purpose of this study, we are concerned only with the fact that Dimmesdale does receive strength and hope from his experience in the forest, and there is no disagreement about that. These are qualities which are given only by the forces of nature. They are alien to the Puritan society. For a pitifully short time, Dimmesdale has been true and honest with himself and with those whom he deeply loves. Now for the first time he has deliberately rejected his intellect and has chosen to follow the dictates of his heart. Gross suggests that thus far in the romance "orthodoxy .. has had its chance--and failed! Now human love--ex-

$$
8 \text { Michaud, P. } 258 .
$$

9Frederick Crews, "The Ruined Wall," Twentleth Century Interpretations of "The Scarlet Letter," ed. John C. Gerber 
alted and consecrated--is to have its chance. "10

There are several ways, however, in which Hawthorne indicates that Dimmesdale has not completely renounced his need for acceptance in a society. When Hester suggests that he choose between living in the wilderness and being "the teacher and apostle of the red men . . or a scholar and sage among the wisest and the most renowned of the cultivated world," Dimmesdale chooses English society rather than the untamed regions of America (p. 198). In addition, the minister is very anxious to be able to deliver his Election Sermon. Although he deceives himself by saying that he wants no man to be able to say that he had left a "public duty unperformed. . or ill performed" Hawthorne states clearly that Dimmesdale is desirous of the honor and acclaim which he will receive (p. 215). Also, when Pearl once more urges the minister to love her mother and herself openly and honestly and to walk into the community with them "hand in hand," Dimmesdale again declines (p. 212). It is pitiful that a man of such potential greatness can be honest for only a brief hour during seven years, and that this honesty is limited to the seclusion of the forest.

Dimmesdale returns to society physically revitalized as a result of his enjoyment of the natural forces around him. He had come to the meeting looking "haggardand feeble" and had found it necessary to walk with the aid of a roughly hewn cane (p. 188).

(Englewood Cliffs: Prentice-Hall, 1968), p. 99. ${ }^{10}$ Gross, p. 364. 
By contrast, he leaves the heart of the forest "at a rapid pace" (p. 216). Crews points out "the implicit sexuality of his crosscountry run, as he 'leaped across the plashy places, thrust himself through the clinging underbrush, climbed the ascent, plunged into the hollow. "II Feidelson states that in this scene, Dimmesdale has reached "the nadir of freedom" (Feidelson, p. 68). Dimmesdale himself considers his new freedom as "deadly $\sin$ " (p. 222). He has traded the stern strength of his religion for the lawless freedom of the physical universe. Instead of striking a balance between the two as Hester has attempted to do, Dimmesdale veers from one extreme to the other, from the head of society to the heart of nature. Because he considers his decision to be evil, he is tempted as never before, to do evil.

Returning to his study, Dimmesdale is suddenly struck with the reality of his religion. A new man physically, he eats "with ravenous appetite" and attacks his Election Sermon "wi th such an impulsive flow of thought and emotion that he fancied himself inspired" (p. 225). At this point in the action, Dimmesdale is being supported both by the forces of nature which strengthen him physically and by the iron framework of his religion which supports him intellectually. The result of such a combination is magnificent. Dimmesdale's Election Sermon is eloquent. "Never had man spoken in so wise, so high, and so holy a spirit... nor had inspiration ever breathed through mortal lips more evidently than it did 
through his" (p. 248). It is significant to point out that Dimmesdale makes specific reference in his sermon to the communities of mankind being built out of the wilderness. Infused by the happiness and hope borne of his experience in the wilderness, Dimmesdale deals with the subject of the future in his sermon. Unlike the other Puritan elders who have reverence only for the past, Dimmesdale has been freed from such blindness, and he now looks into the future "to foretell a high and glorious destiny for the newly gathered people of the Lord" (p. 249).

At the conclusion of the sermon, Dimmesdale is absolutely sapped of his strength. He had channeled all his physical and intellectual energies into the creation and performance of this sermon. Almost too weak to walk, he must rely again on Hester's natural strength to support him so that he can experience his third and last moment of honesty and truth. He is aware of the fact that he is dying, and he knows that the dream of freedom and happiness is an impossible one. He knows also that "all the powers of nature call - . earnestly for the confession of $\sin ^{\prime \prime}(p .131)$.

It is interesting to note Hawthorne's use of light imagery in the minister's three periods of honesty. Each time Dimmesdale is accompanied by Pearl, a playmate of sunshine who urges the minister to be totally honest. The first period of concealed truth takes place in the absolute absence of sunlight. The second occurs within the shadows of the dark forest, and the thi rd happens at noon when the sun is the highest and strongest. With each step, the minister comes closer to disclosing the full truth, and with 
each step the sun becomes brighter.

Because his confession is voluntary, Dimmesdale is reconciled with his society. For the first time in over seven years, and for the last moments of his life, he is bold and honest and true. Significant also is the fact that as the minister is renewing his honest relationship with his society, Pearl is also converted to a life which would combine the elements of nature and society and she "would grow up amid human joy and sorrow" (p. 256). Dimmesdale's confession of paternity has linked Pearl to the electric chain of humanity and she is no longer relegated to the lawless wilderness of nature.

The freedom of the forest had been inviting, but Dimmesdale knows that it must be balanced by the structure of a society. Dimmesdale learns from his experience that the lawlessness of nature provides man with strength, joy, hope, and creativity, but he is also aware that these must be tempered by reverence and compliance with God's laws. Dimmesdale asks (and Hawthorne implies) "is not this better... than what we dreamed of in the forest?" (p. 254). 
In the character of Pearl, Hawthorne has created a pure product of nature. She inherits all the characteristics of the natural universe around her. Just as the forest has a mysterious beauty which is inviting and alluring, Pearl exhibits a "faultless beauty" and a "wild-flower prettiness" (p. 90). Hawthorne chooses to describe her appearance with the same words he has used to describe nature. Pearl has

rich and luxuriant beauty; a beauty that shone with deep and vivid tints; a bright complexion, eyes possessing intensity both of depth and glow, and hair already of a deep, glossy brown, and which, in after years, would be nearly akin to black. (p. 101)

Just as Hester and Dimmesdale had been affected by the "luxuriant" beauty and fecundity of the forest, Pearl is described as a "flower" borne "out of the rank luxuriance of a guilty passion" (p. 89). Her character is so clearly carved out of the world of nature that it is often difficult to conceive of Pearl as a child at all. She seems, both to Hester and to the reader, more like an "airy sprite" or a "little elf" who is much more at ease in the forest than in the confines of the community (p. 92).

The idyllic innocence of the world of nature which Haw thorne had worshipped while living at the 0ld Manse can also be seen in Pearl's composition. Given to Hester as a redemptive force from God, Pearl is "worthy to have been brought forth in Eden; worthy to have been left there, to be the plaything of the angels" (p. 90). Waggoner states that Pearl is "as incapable of 
deceit or dishonesty as nature itself" (Waggoner, p. 145). While all the other major characters in The Scarlet Letter are at times tempted or equated with the sins of the malevolent Black Man of the wilderness, Pearl alone is immune to his spell. The Black Man haunts all the members of the Puritan society with the threat of ubiquitous evil, but as the child boasts, "he cannot catch little Pearl" (p. 134). In her innocence, the child is fascinated with the concept of evil. She asks her mother repeated questions about the Black Man and the effect he has on those who meet with him in the forest. She learns about the existence of the Black Man from a woman in the Puritan society, for the forest holds no danger for the child. She exemplifies, Fogle states, "the divine innocence of childhbod" (Imagery, p. 26).

In her presence, the forest is transformed into the Garden of Eden before the fall. She shares a deep sympathy with the flowers and animals in the woods, and they welcome her as a kindred spirit.

The small denizens of the wilderness hardly took pains to move out of her path. A partridge . . clucked to her young ones not to be afraid... a pigeon ... uttered a sound as much of greeting as alarm... A fox looked inquisitively at Pearl. . . A wolf . . came up, and smelt of Pearl's robe, and offered his savage head to be patted by her hand. (pp. 204-205)

To others, the forest is dark, mysterious, and threatening, but Pearl is covered by no such shadow. She is enveloped in sunshine. The trees seem to step aside in order that the sunbeams can constantly touch her. Fogle finds that "the sun persistently follows her," but it "shines only fleetingly on Hester and the minister" who make an effort to bury the sympathy they feel with 
the forces of nature (Imagery, p. 36). Pearl is by her very nature "in closest sympathy wi th the antique wood," and she makes no effort to change (p. 205).

Unlike her Puritan peers, Pearl is characterized as having major gifts of creativity and imagination. She has inherited her mother's artistic creativity; with the wild flowers and fresh leaves of the forest, she actually creates a natural costume for herself and becomes a "nymph -child" or an "infant dryad" (p. 205). In addition, Pearl's imagination is capable of creating a play world around her. While other Puritan children amuse themselves by imitating their parents, Pearl's ingenuity is unbounded. 'The spell of life went forth from her ever creative spirit, and communicated itself to a thousand objects. . . It was wonderful, the vast variety of forms into which she threw her intellect, with no continuity" (p. 95).

While Pearl shares the beauty, innocence and creativity of nature, she also shares in the lawlessness and mystery of the physical universe. She is characterized by a singular defiance of regulations.

The child could not be made amenable to rules. In giving her existence, a great law had been broken; and the result was a being, whose elements were perhaps beautiful and brilliant, but all in disorder; or wi th an order peculiar to themselves, amidst which the point of variety and arrangment was difficult or impossible to be discovered. (p. 91)

While Hester attempts to discipline the child according to the customary rules and punishments of the period, society's strictures are ineffectual when applied to Pearl. Hawthorne is careful to emphasize the fact that Pearl is immune to any form of discipline, 
"whether addressed to her mind or heart" (p. 92). She knows only the lawless freedom of the physical universe, and she reacts accordingly. "It was as if she had been made afresh, out of new elements, and must perforce be permitted to live her own life, and be a law unto herself" (p. 135).

In 1841 there is an entry in Hawthorne's Notebooks which describes the mi raculous diversity of nature. He gives an account of the variety of moods which nature puts forth. He is amazed at the ease wi th which a violent temper is replaced by sunny cheerfulness. With no small degree of wonder, he reports that al though

there has been a violent storm and rain... this morning shone as bright as if it meant to make up for all the dismalness of the past days. (Notebooks, p. 80)

In the same passage he notes that "on Sunday... there was a fall of snow; which ... did not lie on the ground a moment" (Notebooks, p. 80). Hawthorne faithfully invests Pearl's temperament with this same multiform character. "Pearl's aspect was imbued with a spell of infinite variety" which is an amazement to all who know her (p. 90). She is gifted wi th the same "outward mutability" as is nature, and her disposition is capable of the same violence of passion ( $p, 90)$. Her. moods are many and varied; they change from moment to moment, but they are most like the deep heart of nature in that they are all deeply passionate. Pearl is capable of going into paroxysms of joy or rage which come and go as quickly as the sun passes behind a cloud and returns again. When confronted with her mother's unhappiness, Pearl might 
frown, and clench her little fist, and harden her small features into a stern, unsympathizing look of discontent. Not seldom, she would laugh anew, and louder than before... or . . She would be convulsed with a rage of grief, and sob out her love for her mother. $(p, 69)$

Her emotion is seldom marked by tenderness, but she proves that she is capable of it. In the Governor's mansion Pearl softly lays her cheek on Dimmesdale's hand with a "caress so tender" that it surprises Hester. This mood, however, is seldom seen and is quickly over. It is replaced by the "wild energy" which is more natural to the child (p. 95). It is this deep passionate nature which causes Fogle to conclude that Pearl "is rather fire than sunlight" (Imagery, p. 29). Hawthorne has carefully constructed her character to suggest this relationship. He states that "there was fire in her and throughout her'l (p. 101). He carefully describes her dress of "crimson velvet ... abundantly embroidered wi th ... gold thread" and suggests that she is "the very brightest little jet of flame that ever danced upon the earth" (p. 102). It is quite clear that Pearl has inherited the unleashed passion of her mother's heart, and that she shares the deep and burning life force of nature.

In The Scarlet Letter Michaud finds examples of "paganism and the joy of living, the love of love, the delight in voluptuousness."1 Pearl's character is imbued with these qualities. She is wilder than the pagan Indians of the forest and is composed of a mysterious wild energy which is natural to the "moral wilder-

'Michaud, p. 254. 
ness" of the forest (p. 183). Waggoner points out that, like the forces of nature, Pearl is "not good or bad, because she is not responsible" (Waggoner, p. 145).

She is not in the least affected by the moral laws of the society in which she lives. She is a creation of the natural elements, and she neither accepts nor does she expect membership in the human community. With Hester, she is ostracized by the Puritan populace, and there is an "inviolable circle" drawn around her which admits no friendship and allows no escape (p. 93). In addition, Pearl is regarded as a token of evil by the society. People view her as an "imp of evil" who has "no right among christened infants" (p. 93). Reported to be a "demon offspring," her purpose, the townspeople surmise, is to "promote some foul and wicked purpose" (p. 99). She appears to be considered as much a threat to the Puritan populace as the Black Man is. The child senses her isolation and makes no attempt to become accepted by her society. She knows that she is both distrusted and feared by other children, and she returns these sentiments with "the bitterest hatred that can be supposed to rankle in a childish bosom" (p. 94). She creates no human playmates for her friends, but instead imagines that the pine-trees, "aged, black, and solemn, and flinging groans and other melancholy utterances on the breeze" are the Puritan elders (p. 95). Pearl selects "the ugliest weeds of the garden" to be their children whom she destroys with a vengeance (p. 95). She delights in threatening and frightening the young Puritans whom Hawthorne describes as "somber little urchins" who are "the most 
intolerant brood that ever lived" (pp. 102, 94).

Pearl appears to have no sympathy for humanity. She often treats her mother's unhappiness with mocking indifference. Irreverently she dances on the tombstones of departed Puritan leaders and splashes water on the Governor of Boston. Chillingworth, himself separated from the circle of human sympathy, is amazed at Pearl's complete disregard for society. He expressed dismay in that "there is no law, nor reverence for authority, no regard for human ordinances or opinions, right or wrong, mixed up with that child's composition" (p. 134).

Not only does the child lack human sensitivity, but she also completely rejects the moral laws of the society. She announces to her mother that she has "no Heavenly Father" even though her mother had carefully instructed her as to the religious bellefs of the Puritan society (p. 98). Later, when closely questioned by Mr. Wilson, she reiterates this idea by stating that she had not been created by God, but "had been plucked by her mother off the bush of wild roses, that grew by the prison-door (p. 112). The importance of the clergy in the Puritan society is meaningless to Pearl, for she happily hurls burrs at Dimmesdale and stubbornly refuses to cooperate with Mr. Wilson. She identifies herself as her "mother's child" only, and indeed she may well be the pure product of Mother Nature (p. 110).

Consequently, Hawthorne links this child to other products of nature. She is described as a "wild, tropical bird, of rich plumage" who is too wild to be confined on the Puritan soil, but 
who flies into the infinite freedom of the skies (p. 111). Likewise, the child is constantly bathed in sunshine. She catches and plays with the sunbeams as other children play with toys. More than any other natural symbol, however, Pearl's character is equated wi th the wild red rose. The area outside the prison is marked by the unsightly weeds of the unsympathetic society and the beautiful red rose of nature. Pearl, like the rose, miraculously thrives in the barren and sterile Puritan soil. On seeing her in the Governor's mansion, Mr. Wilson announces that Pearl should have been named "Red Rose, at the very least," for she is so brilliantly dressed in that hue $(p \cdot 110)$. Hester encourages the child to go to the Governor's house by promising that they might see lovely flowers in the garden which is adjacent to the house. Later, when she sees the rose bushes, Pearl begs to be given one of the flowers. Urged by Mr. Wilson to explain her birth, Pearl announces that she 'had been plucked by her mother off the bush of wild roses, that grew by the prison door" $(p, 112)$. Waggoner points out that Pearl has all the "naturalness and beauty of the rose, and like the rose she is a symbol of love and promise" (Waggoner, p. 133). By connecting Pearl's character with the rose as he does, Hawthorne is implicitly implying that her character is a lovely product of natural freedom.

Because she is so closely allied with the world of nature, it is no wonder that the Puritans view her as an enigma. Both Dimmesdale and Chillingworth, characters who are lacking the qualities of nature, question the child's temperament. She is like 
the mysterious wilderness which surrounds the settlement, and they cannot ascertain whether she has "any discoverable principle of being" or not (p. 134).

Just as there are many moods to Pearl's temperament, so too, are there many allegorical symbols connected with her character. Male states that the character of Pearl "signified truth and grace" (Male, p. 94). There is a great deal of evidence to support his interpretation, for Pearl constantly demands the truth from Hester and Dimmesdale alike. She constantly questions Hester about the origin of the scarlet letter, and she demands to know the truth about the Black Man. She will not tolerate Dimmesdale's dishonesty and persistently urges him to stand with her and her mother, hand in hand, in the sunlight. The importance of the sunlight, which seems to be Pearl's constant companion, should not be under emphasized. The bright sunlight prohibits the shadow of secrecy which envelops Dimmesdale's character. It also protects Pearl from the darkness of evil which is constantly equated with Chillingworth's character.

Pearl is suggestive of the idea of grace, as Male points out, because she is at once "a token of $\sin$ and a promise of redemption" (Male, p. 9). Hall concurs with this conclusion when he points out that "Pearl stands for Hester's obligation to society" (Hall, p. 168). The child binds Hester to the morality of the community. She acts as a "blessing... to keep the mother's soul alive" (pp. 114-115). Pearl is a source of torment at the same time, for she reminds Hester, "at every moment, of 
her fall" (p. 115). Daniel Hoffman states that "as long as Hester is responsible for Pearl--who represents both the emblem of her sin and, as grace, the possibility of her own redemption, she will be proof against the Black Man's coven. 112

After leaving the Governor's house and having been granted the privilege of raising her child, Hester states that Pearl protects her from the Black Man's amoral world. Urged by Mistress Hibbins to venture into the forest, Hester answers honestly that she must attend to her child. If not for Pearl, she would gladly have sacrificed herself to an immoral life. Pearl seems ever faithful to her mission of saving Hester. As an infant, the child's first awareness is not of Hester's smile, but of Hester's token of sin. As she grows, "Pearl's inevitable tendency to hover about the enigma of the scarlet letter seemed an innate quality of her being" (p. 180). She lines her mother's letter with both roses and burrs, and later creates a duplicate letter for her own chest, made out of natural elements rather than cloth. With increasing persistence, she showers her mother with questions concerning the the scarlet token. After Hester decides to speak to Dimmesdale about the doctor, Pearl's interest in the scarlet letter becomes even more intense. "Two or three times... and as often at

2Daniel G. Hoffman, "Hester's Double Providence: The Scarlet Letter and the Green," Form and Fable in American Fiction (New York: 0xford University Press, 1961), rpt. In Nathaniel Hawthorne, The Scarlet Letter, ed., Scul ley Bradley, Richmond Croom Beatty, and E. Hudson Long (New York: W. W. Norton 8 ., 1962), P. 371. 
suppertime, and while Hester was putting her to bed, and once after she seemed to be fairly asleep," Pearl confronts her mother wi th the inevitable question, "and the next morning, the first indication the child gave of being awake" was her asking why the minister kept his hand over his heart (p. 181).

Hester realizes that "Providence had a design of justice and retribution, in endowing the child with this marked propensity" (p. 180). She knows that Pearl has been provided to her in an effort "to help her to overcome the passion, once so wild, and even yet neither dead nor asleep" which threatens to rob her soul of its salvation (p. 180). She is aware of the fact that she, no less than the minister, must "be true" to the token of her sin, but under the pressure of Pearl's repeated questions, Hester lies to the child, stating that she wears the scarlet letter for "the sake of its gold thread" (p. 181). Later, she demands that Pearl stop talking about it and threatens to shut her in a closet if she does not mind. In this manner, Hawthorne foreshadows the actions and attitudes of Hester in the forest.

While Pearl leaves Hester alone with Dimmesdale in the forest, the two lovers plan to escape from the confines of the society and to reaffirm their love. In a symbolic gesture, Hester hurls the letter from her. Hoffman notes that "when Hester strips herself of the scarlet letter, she regains her pagan sexuality in the heathen world of Nature, beyond human law and divine truth.113 
Again Pearl saves her mother from irrevocable sin by forcing Hester to take up the token of her sin and to wear it. Pearl identifies her own personality with the scarlet letter, and when Hester discards it, Pearl resents the abrupt change in her mother's attitude. Feidelson points out that in throwing away the scarlet letter, Hester has leveled the distinction between ideal and human freedom; there is no human world for Pearl to return to" (Feidelson, $x$ p. 76). Pearl demands her place in the world, and her place is beside Hester. Her purpose is to link her mother to the morality of society by reminding her of her sin and thereby helping her to repent of it. Male believes that Pearl's actions indicate to Hester and Dimmesdale the fact "that their proposed escape from time into motion and space is an unrealizable dream--or at least can be effected only at the cost of leaving their salvation behind" (Male, p. 112).

In addition to being the agent of Hester's salvation, Pearl plays another important role in Hawthorne's romance. She is the link which connects Hester and Dimmesdale in an "electric chain" of humanity (p. 153). Again and again she asks Dimmesdale to join hands with Hester and herself. When the minister does, Feidelson contends that the sanctity of their relationship "is validated when the celestial 'A' shines down upon this archetypal trio: Pearl, 'herself a symbol,' is the human counterpart of the divine signature in the sky" (Feidelson, p. 76).

Later, in the forest, Dimmesdale and Hester recognize her as "the visible tie that united them" (p. 206). In their child, 
they see the beauty and majesty of "the oneness of their being" (p. 207). Just as the child serves to connect Hester with the society in which she lives, she also binds her to the man she loves. Thus she prohibits Hester from divorcing herself completely from the sphere of humanity--Chillingworth's particular fate.

Hugh Maclean states that Pearl's quest throughout the first seven years of her life is explained by Hester as she stands on the scaffold before the Puritan community. Exhorted to name the child's father, Hester defiantly announces "my child must seek a heavenly Father" (p. 68). Maclean suggests that "this quest, which is unconscious and involuntary" comes to an end exactly where it began seven years earlier. ${ }^{4}$ As long as Pearl has only a mother and no father, her life is incomplete. She lives on one plane only. Hoffman points out that until Dimmesdale "acknowledges himself as her father she can have no human patrimony, and must remain a Nature spirit, untouched by the redemptive order that was broken in her conception. 15

When she is united with her father by the honest confession of his relationship to her, "a spell was broken" (p. 256). Pearl's existence as a product of nature alone comes to an end. Hawthorne had stated that the child needed to be affected by deep sorrow in

4Hugh Maclean, "Three Epic Quests," Iwentieth Century Interpretations of "The Scarlet Letter," ed. John C. Gerber (Englewood Cliffs: Prentice-Hall, 1968), p. 55.

5 Hoffman, p. 371. 
order to awaken the human tenderness and sympathy of which she is capable. 'The great scene of grief... had developed all her sympathies; and as her tears fell on her father's cheek, they were the pledge that she would grow up amid human joy and sorrow, nor for ever do battle with the world, but be a woman in it" (p. 256). Fairbanks points out that human suffering is "a part, and a necessary part, of human experience--the humanizing part."16 This scene marks an end to Pearl's exclusive alliance with nature, and it also brings an end to her "errand as a messenger of anguish" to her mother (p. 256). Male notes that in this dramatic scene Pearl "shifts from her role as the universal principle in the spiritual realm.. to the social world" (Male, p. 97).

Hawthorne's statement that Pearl 'became the richest heiress of her day" can be interpreted as an allusion not only to the monetary wealth she inherits from Chillingworth, but also to the wealth of character which she inherits from her two parents (p. 261). In her can be found deep passion, beauty, creativity, and strength of character which she inherits from Hester. These qualities are joined by Dimmesdale's deep sensitivity, his adoration of purity and morality, and his tremendous compassion for humanity. She is the 'material union and the spiritual idea in whom they met, and [in whose person] they were to dwell immortally together" (p. 207). Ultimately in Pearl we have the

\footnotetext{
6 Fai rbanks, p. 88.
} 
balance of the forces of nature and the laws of society. She, in contrast to the other characters of the book, reconciles the problem of the head and the heart. Therein lies her true wealth. Just as Pearl puzzled the Puritans, so too has she confounded the critics. There are innumerable theories and explanations of her character. The very elusiveness which made Hester doubt that "Pearl was flesh and blood, and not utterly delusive" has made the majority of critics conclude that she exists more as a symbol than as a character (p. 92). F. 0. Matthiessen finds that Pearl "may well be the most unpopular little girl in fiction."17 Wagenknecht states that Pearl "is the one straight allegorical personage in the book. ${ }^{18}$ Gorman agrees that she is "no more than an animated symbol introduced to emphasize certain important moments in the limited but intense action of the book. 19 Fogle allies himself with this side of the controversy, stating that Pearl exists as a symbol rather than a character who represents "original sin" (Imagery, p. 26). By contrast, Woodberry argues that "the child fulfills the function of the chorus in the old drama, in part a living comment, in part a spectator. "10

7F. 0. Matthiessen, American Renaissance: Art and Expression in the Age of Emerson and Whitman (New York: Oxford University Press, 1941), rpt. in Nathaniel Hawthorne, The Scarlet Letter, ed., Sculley Bradley, Richmond Croom Beatty, and E. Hudson Long (New York: W. W. Norton \& Company, 1962), p. 275.

8 Wagenknecht, Cavalcade of the American Novel, p. 45.

${ }^{9}$ Gorman, p. 252.

10 Woodberry, p.192. 
It is important to note that Pearl is created from the model of Hawthorne's own child, Una. His Notebooks abound with descriptions of his daughter, and Mark Van Doren has carefully analyzed those sections of Hawthorne's notes which directly pertain to Pearl's characterization. "I Hawthorne is honest in his sketches of the daughter he cherishes for he presents both her strengths and her weaknesses. He is at once delighted and mystified by her actions and attitudes. For this reason, Waggoner states that it seems "curious that most readers find it harder to 'believe' in Pearl than in any other major character in the book except perhaps Chillingworth" (Waggoner, p. 145).

It is interesting also to note a journal entry made in October of 1841 which describes a young girl who visits the 01d Manse.

She is very vivacious and smart, laughing, singing, and talking, all the time... healthy as a wild flower, she is really very agreeable; and to look at her face is like being shone upon by a ray of sun. She never walks, but bounds and dances along; and this motion... is like a bird, hopping from twig to twig, and chirping merrily all the time. (Notebooks, p. 82)

Later, Hawthorne makes note of the young girl's creativity.

She strings the seed-berries of roses together, making a scarlet necklace of them, which she wears about her neck. She gathers everlasting flowers, to wear in her... bonnet, arranging them with the skill of a dress-maker. (Notebooks, p. 82)

These descriptions are meant to be both truthful and believable.

11 See Mark Van Doren, Nathaniel Hawthorne (New York: William Sloan Associates, 1949), Pp. 150-154; 156-166. 
They are so very similar to Hawthorne's characterization of Pearl, that it appears that the author intended Pearl to be portrayed as a believable character at least. There is no doubt, however, that he also used her to suggest many various allegorical meanings. Brownell, in fact, feels that

Pearl herself is a jewel of romance. Nothing more imaginatively real than this sprite-like and perverse incarnation of the moral as well as the physical sequency of her parents' sin exists in romance. Her individuality is an inspiration deduced with the logic of nature and with such happy art that her symbolic quality is as incidental in appearance as is seen to be inherent on reflection. 12

This critical argument, however, does not affect the fact that it is in Pearl's character that Hawthorne makes it implicitly clear that a life which is connected solely with the realm of nature or with the sphere of society is incomplete. Pearl "is a symbol of what the human being would be if his situation were simplified by his existing on the natural plane only, as a creature" (Waggoner, p. 145). Only when Pearl reconciles herself to the society; only when she balances the elements of nature and society in her life, can it be said that she leads a full or a happy existence.

12W. C. Brownel1, "The New England Faust" American Prose Masters, (New York: Charles Scribner's Sons, 1909). rpt. in Nathaniel Hawthorne, The Scarlet Letter, ed., Schulley Bradley, Richmond Croom Beatty, and E. Hudson Long (New York: W. W. Norton \& Company, 1962), p. 249. 
In the character of Roger Chillingworth, Hawthorne has personified the tragedy of a man completely divorced from the natural universe and from the community of mankind. He is a man of magnificent potential who is capable of being a leader in society. He is born with a deep sensitivity and intellect which provide him with the answers to many of nature's secrets. If he had been capable of combining these talents, if he had been able to develop his intellect without stifling his heart, he would have been able to enjoy both fame and love. Chillingworth fails, however, to achieve a balance between the qualities of the head and the heart. He, more than even Dimmesdale, suffers as the result of the separation of the mind from the body.

This characteristic dialectic between the powers of the intellect and the forces of the heart is central to the Puritan community. Chillingworth has much in common with the society in which he lives. He is, more than any other character in the book, ruled by his intellect. A tremendously brilliant scholar, he describes himself as "a man of thought,--the bookworm of great libraries,--a man al ready in decay, having given my best years to feed the hungry dream of knowledge" $(p .74)$. He is, before he learns of Hester's adultery, apparently a good man. In fact, he might be described as an exemplary Puritan who has developed all the qualities which the Puritan society would applaud and who has controlled or destroyed all the human passions which the society would despise. 
Chillingworth states that his life is "made up of earnest, studious, thoughtful, quiet years, bestowed faithfully for the increase of ... knowledge...faithfully for the advancement of human welfare" (p. 172). No goals could have been more acceptable to the Puritan ethic. Chillingworth shares the Puritan adoration of books and knowledge.

Likewise, Chillingworth has achieved the Puritan goal of denying his passionate nature. 'He had so cultivated his mental part that it could not fail to mold the physical to itself" $(p, 60)$. It is meaningful, therefore, to note that Chillingworth's physical body, in contrast to his mental powers, has not fully developed itself. It is deformed because it has been denied its full and natural place in his life. Before his arrival in Boston, Chillingworth states that he had been a man who was "cold, nevertheless a man thoughtful of others, craving little for himself,--true, just, and of constant, if not warm affections" (p. 172). Chillingworth shares this lack of passion with the other Puritan elders. They have also destroyed the potential passion within them.

It is important to note that both Chillingworth and the Puritan society take on themselves the office of judging and punishing the sins of others. Because they are equally lacking in the qualities of the human heart, they are ill-equipped to "meddle with a question of human guilt, passion, and anguish" (p. 65). They are incapable of either empathy or sympathy. They have no right, therefore, to be in the judgment seat. God alone, Hester insists, has the right to punish. 
Nevertheless, these individuals consider themselves capable of judging man's passionate nature. The similarity between Mr. Wilson, the disciple of God, and Roger Chillingworth, later recognized as "Satan's emissary," cannot be ignored (p. 128). Both are scholarly and studious. While Wilson's eyes are pained by the potency of the sunlight, Chillingworth's eyes are also "dim and bleared by the lamplight" (p. 58). Both men are "well stricken in years" and share the same thwarted potential for kindness and compassion (p. 58). Most importantly, both scholarly men are in agreement with the philosophical foundations of the Puritan theocracy. Feidelson points out that Chillingworth's "thought, as he himself comes to see, is dominated by Puritan concepts... Moreover, the amorality of Chillingworth ... derives from the negatively liberated, disjunctive world of Puritan theology" (Feidelson, p. 71). Just as Wilson's religion holds sin as its dominant concept, so too does Chillingworth allow the concept of sin to become central to his life. Basing its foundation on the idea of man's depravity as a result of original sin, the Puritan theocracy expends its energies in an effort to purge itself of human sexuality. Chillingworth's energies are also wasted in an effort to punish the same type of sinfulness. John Hart points out that just as the Puritans' "repressed feelings have festered into a passion that pries into other people's hearts, so Chillingworth's emotions are manifested in hatred."1

'John E. Hart, "The Scarlet Letter: One Hundred Years After," New Engl and Quarterly, XXIII (1950), p. 387. 
Likewise, both Chillingworth and the Puritan society concentrate their efforts on the punishment of sin. Hester's punishment is to last for her entire lifetime, and it is interesting that some members of the community consider her punishment to be excessively lenient. The practice of forgiveness does not appear to be condoned by the society. Similarly, Chillingworth considers punishment as his eminent domain. Although Hester pleads with the physician to "forgive and leave... further retribution to the Power that claims it," Chillingworth rejects the very possibility of forgiveness (pp. 173-174). Feidelson points out that "Chillingworth counters her appeal by falling back on the Puritan language of original sin and abstract wickedness" (Feidelson, p. 71).

It is an interesting fact that the graveyard which has a very prominent place in the Puritan society, is also of central importance to the physician. Not only does he live in a house which is immediately adjacent to the graves of Puritan elders, but he also depends on this melancholy plot of land for the production of herbs and weeds for his medicines. It is poignantly ironic that Chillingworth would search an area of death for the means of preserving life.

Because Chillingworth has many qualities which are shared by the Puritan community, he is immediately accepted into the fold. He has the appearance of humility, and appearances are of utmost importance to the Puritan society. When Hester adopts the guise of humility and repentance, her scarlet letter comes to hold a more complimentary meaning for the townspeople. Because 
Dimmesdale's appearance is one of innocence and piety, he is not suspected of $\sin$ by the society. Thus because "the learned stranger was exemplary, as regarded at least the outward forms of a religious life," he is enthusiastically welcomed by the Puritan society (p. 120). Hart suggests that "Chillingworth's actions can go undetected in a society characterized by decay whereas Hester's cannot. Without violating any moral code of society, he can pursue punitive measures in being his brother's-if not his wife's--keeper." ${ }^{2}$

Al though the physician has many characteristics in common with the Puritan society, the differences which divorce him from that society have a much greater effect on him. While the founders of Puritanism based the civil laws of the community on the moral laws of God, Chillingworth's world becomes devoid of the concept of God. Feidelson suggests that Chillingworth lives in "the orthodox Puritan world but wi thout the God against whom the Puritans measured it and by whose power they believed it might be saved as well as damned" (Feidelson, p. 71). Chillingworth's life has no pure purpose as does the Puritan settlement. Instead, Chillingworth represents the opposite extreme. He admits to Hester that he is "a fiend whose purpose is not to save souls but to damn Dimmesdale irrevocably (p. 173). Woodberry sees Chillingworth as the "devil of hate" living in the Godly Puritan community. ${ }^{3}$ Hall adds that Chillingworth represents the "operation

$$
2 \text { Hart, p. } 387 .
$$


of ethical precepts, which were originally designed to enable men to live harmoniously in society, so divested of their Indwelling humanity that they become a force of devastation" (Hall, P. 172). The concept of confession is an important one to the Puritan community where public punishment is intended as a means of redemption. Voluntary confession establishes an honest relationship between the individual and his society. Such honesty makes penitence possible. Chillingworth, by contrast, encourages Dimmesdale to keep his sin hidden and, therefore, to perpetuate his hypocrisy. Although Chillingworth urges the minister to "lay open . . the wound or trouble in your soul," the manner in which he attempts to pry the confession from the tormented minister, actually encourages him to bury the secret even deeper in his heart (p. 136). This silence allows the physician to dissect his patient figuratively by going "deep into his patient's bosom, delving among his principles, prying into his recollections, and probing everything with a cautious touch" (p. 124).

His power over the minister demands the symbolic darkness of secrecy and cannot survive the honesty of the sunshine. Therefore, the physician is covered by shadows, and Fogle points out that the "sun runs from him" (Imagery, p. 36). At midnight when Dimmesdale makes a feeble and abortive attempt to confess, Chillingworth urges him to return to bed and to forget his folly. Later, before Dimmesdale actually confesses to the entire Puritan community, Chillingworth attempts to snatch his prey back from 
salvation. He announces to Dimmesdale that he could have saved himself through no other means except public confession. "Hadst thou sought the whole earth over,... there was no one place so secret,--no high place nor lowly place, where thou couldst have escaped me,--save on this very scaffold!" (p. 253). When Chillingworth alone knows the secret of Dimmesdale's sin, he is capable of causing the minister unutterable pain, but after Dimmesdale's confession is heard by his society, Chillingworth no longer has any power over his patient.

It is by gradually becoming an agent of damnation rather than salvation that Chillingworth isolates himself from the human society. Hart notes that "his guilt.. is that of a diseased mind which puts its complete hope in intellect, not passion, and which leads to decay, not growth and understanding. $1{ }^{4}$ His initial mistake is made when he attempts to share in the experience of a close comradeship with mankind by marrying Hester. The marriage is sought, not because of a natural need for Hester as a woman, but because the physician reasons that he can vicariously share the joy of life by experiencing it through Hester. He explains that "up to that epoch of my life, I have lived in vain. The world had been so cheerless! My heart was a habitation large enough for many guests, but lonely and chill, and wi thout a household fire"(p. 74). The marriage is without love, and Chillingworth admits that he should have been able to predict the sad result.

$$
4 \text { Hart, p. } 387 .
$$


Arvin contends that "the initial wrong was committed by the aging man of science who tried to bring warmth into his own benumbed existence by attaching to himself the radiance and vigor of Hester's youth. "5 Chillingworth himself views the union as "false and unnatural," al though it is the only means by which he can bring joy into his life $(p .75)$. Hester remembers her marriage as a life "feeding itself on time-worn materials, like a tuft of green moss on a crumbling wall" (p. 58). Her beauty and fertility, as symbolized by the color green, had been joined to the decay and sterility of Chillingworth's character.

While Hester reacts to life and to people in a purely emotional manner, her husband studies them with objectivity. He is capable of viewing Dimesdale as a mere machine rather than a human being. Absolutely wi thout passion or compassion, he places the minister under scientific scrutiny in order to ascertain "the spring that controlled the engine" (p. 140). This deficiency in the quality of human sympathy is what causes Chillingworth's isolation from Hester and his eventual isolation from mankind. Darrel Abel notes that "more perilous to the soul even than the aberrations of the passion... is the reliance on the intellect alone as a sufficient instrument of knowledge. 16

Faced with the reality of Hester's adultery, Chillingworth is not seized by jealous wrath, but instead, he begins "an investigation . . With the severe and equal integrity of a judge"

$$
{ }^{5} \text { Arvin, Hawthorne, p. } 190 . \quad 6_{\text {Abel, p. } 186 .}
$$


in order to give the child a father (p. 129). At length, however, the scholar becomes obsessed by the study of his victim's heart, and it overwhelms him. "A terrible fascination, a kind of fierce, though still calm, necessity seized the old man with its grips, and never to set him free again, until he had done all its bidding" (p. 129).

In order to pursue his study, Chillingworth chooses "to withdraw his name from the roll of mankind... and to vanish out of life as completely as if he indeed lay at the bottom of the ocean" (pp. 118-119). It is important to recognize the fact that he, no less than Dimmesdale, plays the part of a hypocrite. He pretends to dedicate himself to soothing his patient's pain, when he is instead intensifying and prolonging it. He assumes a false identity, and his chosen name suggests his great value and great flaw. The physician is certainly a man of potential worth. His medical knowledge can be very beneficial to humanity, but his heart, chilled into numbness, separates him from the humanity which he could so ably serve and relegates him to a life of intellectual isolation.

Once Chillingworth intuitively senses Dimmesdale's paternity, he designates himself as judge and jailer. His heart, at first merely cool, turns to ice, and Chillingworth becomes diabolical. He is incapable of human sympathy or understanding. Therefore, he cannot and will not forgive Dimmesdale for his sin. Feidelson points out that "the love he once sought with Hester is realized in the hate of his new relationships. His 'human heart,' no longer 
lonely, is expressed in the deeds of a "fiend"' (Feidelson, p. 70). Chillingworth is cognizant of his transformation, and he is horrified by it. Al though he regrets having sacrificed his "human heart," Chillingworth believes that he is powerless to effect a change within himself (p. 172). The "unfortunate physician" believes that it is "fate" which forces him to perpetuate his sin (pp. 172, 174).

Chillingworth is even more dramatically segregated from the beneficial forces of nature than he had originally been from mankind. His state of decay is diametrically opposed to nature's vitality. Old and deformed, Chillingworth is certainly not allied with the beauty and fertility of the forest, nor can he share its deep sympathy with man's passionate nature. On the contrary, Chillingworth is a man of "cold composure" (p. 73). He is, in fact, inçapable of supporting his own physical being. As he becomes more and more dehumanized, Chillingworth is increasingly incapable of sustaining his own strength. Eventually he becomes a parasite and depends entirely on Dimmesdale for life. He feeds on Dimmesdale's anguish. Male points out that "Chillingworth is a leech, draining his patient of nerve, will, and physical energy" (Male, p. 96). Leeches, it should be noted, could be agents of healing as well as harming. If their application served to purge the patient of his infection or "some ailment in the spiritual part," leeches could be beneficial ( $p .136)$. Chillingworth, however, has no intention of ridding his patient of the poisonous guilt which is destroying him. Instead, he burrows into Dimmesdale's heart in an effort to 
find the secrets hidden there. As Chillingworth's search becomes more and more intense, Dimmesdale spends his ebbing energies in an attempt to protect his secret. Chillingworth is, in effect, draining his patient of life. His function is quite the opposite to that of nature, the potent life-giving force.

It is ironic that it is Chillingworth, and not those characters who are closely allied with nature, who most clearly understands the secrets of nature. Chillingworth has combined the wealth of his institutionalized learning with the knowledge he gains from living with the Indians, and the result is that he is a brilliant doctor. He is gifted with the knowledge which society can provide and he has learned the secrets of the natural universe by living in the wilderness. Chillingworth himself boasts that only his excellence has kept Dimmesdale alive. "But for my aid, his life would have burned away in torments, within the first two years after the perpetration of his crime" (p. 171). In this manner, Hawthorne suggests the excellence which could be achieved by the combination of the qualities of nature and society. This goal cannot be reached in Chillingworth's case, because he has sacrificed his heart which separates him from common humanity and also from the beneficial aspects of nature.

Hawthorne is careful to associate Chillingworth with the malevolent aspects of the natural universe. He is equated wi th shadows and darkness as opposed to the brightness and warmth of the sunshine. Hester notes that he seems to be enveloped in an "ominous shadow" which follows him as he moves (p. 175). Fogle 
suggests that the physician 'becomes darker and darker as the romance develops" (Imagery, p. 36).

In addition, Chillingworth is associated with weeds. Constantly collecting herbs and weeds, Chillingworth understands their composition well enough to convert them "into drugs of potency" (p 130). Dimmesdale, who tries to deny his own innate sympathy with nature, notes Chillingworth's knowledge of natural plants and weeds. He is amazed at the physician's ability to ferret out such mysterious herbs. Waggoner notes that

the unnatural flowers and unsightly vegetation are aligned with moral evil, and with Chillingworth in particular. He too in his deformity is 'unsightly.' Low, dark, and ugly, he suggests to some people the notion that his step must wither the grass wherever he walks. (Waggoner, p. 131)

After Dimmesdale's death, Chillingworth has nothing to feed on. Hawthorne emphasizes his sub-human character by stating that he "positively withered up, shrivelled away, and almost vanished from mortal sight, like an uprooted weed that lies wilting in the sun" (p. 260). Waggoner concludes that "flower and weed imagery unites with light and color imagery to define Chillingworth's position as that of the chief sinner"l (Waggoner, p. 132).

In order to illustrate the gradual transformation of Chillingworth into a fiend, Hawthorne clearly connects his character with the image of fire and of the Black Man. Hester first introduces the idea in jail when his acts are benevolent, but she questions his intent by asking if he is "like the Black Man" (p. 77). Pearl also senses Chillingworth's malevolence, and seeing Chillingworth in a nearby window, she warns her mother to stay 
away from the "old Black Man" (p. 134). Chillingworth assumes the character of Satan himself when he discovers the secret of Dimmesdale's heart. Hawthorne emphasizes this image by explaining that "there came a glare of red light out of his eyes; as if the old man's soul were on fire, and kept smouldering duskily within his breast" (p. 169).

It is clear that Chillingworth sins more deeply than either Hester or Dimmesdale. He "had made the very principle of his life to consist in the pursuit and systematic exercise of revenge" (p. 260). He had "violated the sanctity of the human heart" (p. 195). Completely divorced from the vitality of nature and the redemptive strength of society, Chillingworth is inflicted with an isolation which is more extreme than that of any other character. In his introduction to the American Notebooks, Stewart states that in Hawthorne's philosophy the "Unpardonable Sin might consist in a want of love and reverence for the Human Soul (Notebooks, p. Ixxvi). Chillingworth is guilty of both errors. When he sacrifices his human heart, he loses all reverence for the soul of mankind and thus breaks all ties with humanity. His intellect, overpowering his emotions, separates him from the beneficial qualities of nature. It is not surprising that Brownell sees Chillingworth as "an embodied abstraction--the one piece of machinery of the book."7 He is no longer a man. He has been divested of all emotion and is incapable of love, joy, or hope. In 1837, Hawthorne had written a 
letter to Henry Wadsworth Longfellow stating that "there is no fate in this world so horrible as to have no share in either its joys or sorrows."18 This is Chillingworth's fate, and it is in every way the most tragic.

8Nathaniel Hawthorne, The Portable Hawthorne, ed. Malcolm Cowley (New York: The Viking Press, 1969), P. 670. 
Nathaniel Hawthorne's conviction that an individual must reconcile the conflict between the human community and the natural world can be clearly seen in his treatment of the four major characters of The Scarlet Letter. The Puritan society about which Hawthorne wrote and the Transcendental era during which he wrote held widely disparate views concerning these two aspects of life. The Puritans had held a deep distrust of nature which was viewed as lawless and immoral. Their society demanded that an individual deny his emotional impulses and encouraged him to live according to the dictates of the mind alone. The Transcendentalists, by contrast, encouraged man to go to the opposite extreme and to honor the inspiration provided by the natural universe and to distrust the conventions of society.

Hawthorne attempts to find a point of equilibrium between these two opposing views. His characters struggle to find a balance between nature and society, and they suffer as a result of embracing either of the two extremes and denying the other. Each character isolates himself from nature or society and thereby stifles the qualities of either the head or the heart. With each of his major characters, Hawthorne illustrates the unhappy result of an individual's isolating himself from one of the major aspects of his envi ronment.

Hester's character is originally dominated by the demands of her emotion, and she is therefore allied with the forces of 
nature. As a result of ignoring the morality of society, she commits a sin of passion. Her sin results in further isolation from her society, which causes her extreme anguish. In an effort to repent of her sin, Hester struggles to deny her inherent passionate nature. As she tries to ally herself with the Puritan community, she dwells in the realm of intellect alone and ignores her physical being. Failing in this effort, she later reverts to the opposite extreme in defying the ethical code of the society and adopting an antinomian attitude toward life. Throughout the seven years of her life which Hawthorne portrays, Hester vacillates from one extreme to the other. Both extremes are unsatisfactory because they deny an individual his full development of the mind and the emotions. It is not until the end of her life that Hester recognizes the necessity of finding a reconciliation between the demands of society and the qualities of nature. She returns to Boston, lives within the confines of the community, concerns herself with the problems of the human heart, and has hope for a future society which will provide an opportunity for the full development of an individual both emotionally and intellectually. Although Hester had been unable to experience a happy balance in her lifetime, Hawthorne makes it clear that the future may hold such a promise.

Arthur Dimmesdale's struggle to reconcile the conflict between nature and society is as intense and tragic as that of Hester. Dimmesdale makes an attempt to associate himself entirely with his society and to deny his deeply passionate nature. His 
isolation from the natural world around him results in weakness, both physical and moral. His convictions are utterly sincere, but he does not have the strength of character to live up to them. His $\sin$ is a result of the emotional nature which he desperately struggles to deny. His life is filled with torment and misery because he never sees, as does Hester, the necessity of combining the strengths of the natural world with those of society. His death is the result of his increasing physical decay which follows his total alliance with society and his association with the leech. The combination of society's sterility and Chillingworth's gradual drain upon his life force eventually causes Dimmesdale's death. This process is allayed only twice in the entire romance, and both times occur when Dimmesdale comes in contact with the forces of nature. On the scaffold at midnight Dimmesdale is infused with new strength and hope when he takes Pearl's hand. Later in the forest, Dimmesdale is almost intoxicated by the potent atmosphere of nature. In this character Hawthorne makes explicit the importance of man's dependence on the world of nature for physical sustenance and support. By the same token, the minister is equally dependent on the society for intellectual and moral support. Dimmesdale's tragedy results from his ready acceptance of the strength of his society and the constant denial of the importance of the physical aspect of life.

Pearl's life is completely opposite to Dimmesdale's. While he sadly attempts to associate himself entirely with society, Pearl is totally allied with the world of nature. She rejects everything 
which society has to offer. She does not comply with $i$ ts rules and laws, and she has no respect for its leaders or its institutions. The Puritan religion has no place in her beliefs, and she shows much more interest in the Black Man of the forest than she does in the heavenly Father. She does not want or need the companionship of friends, for she is a kindred spirit with the animals in the forest. The result of her rejection of all aspects of society, however, is that Pearl lives an incomplete existence. She lacks the qualities of being human. It is not until her human sympathies are awakened by Dimmesdale that Pearl becomes a part of the society around her. She becomes a rich woman in her adul thood because she combines the qualities of nature and the strengths of society.

Chillingworth also lacks human qualities. He isolates himself from what is good in nature and society by sacrificing his human heart. Existing only on an intellectual plane, he is incapable of experiencing life fully. Any experience he is able to enjoy must be vicarious. Chillingworth does not exist as a man but is reduced to the level of a fiend because he has no reverence for humanity or for the human heart.

The importance of the human heart cannot be underestimated in The Scarlet Letter. Its function is to connect the individual to the world of nature and to common humanity. When Chillingworth sacrifices his heart, he becomes isolated from both essential elements in life. When he "violated, in cold blood, the sanctity of the human heart," he assumed the role of a fiend (p. 195). Likewise, when Dimmesdale and Hester make an attempt to deny the 
demands of their hearts, and to live through the intellect alone, their lives are incomplete and unhappy as a result. Pearl needs to have the sympathy of her heart awakened in order that she can become a member of the human race and thereby live a complete life. Only by the acceptance and reverence of the human heart can an individual be truly a member of the community of mankind and, at the same time, appreciate the qualities of the natural universe. Hawthorne had written a letter to Sophia on October 4, 1840, which expressed his own reverence for the importance of the human heart.

Indeed, we are but shadows--we are not endowed with real life, and all that seems most real about us is but the thinnest substance of a dream--till the heart is touched. That touch creates us--then we begin to be--thereby we are beings of reality and inheritors of eternity. (Notebooks, p. Ixx)

Hawthorne suggests that by fully accepting and honoring the human heart, man can find a balance between nature and society. Hester and Hawthorne look forward to that "brighter period, when the world should have grown ripe for it, in Heaven's own time," when man can live an existence which will allow nature and society to be in concord rather than conflict (p. 263). 


\section{A SELECTED BIBLIOGRAPHY}

\section{PRIMARY SOURCES}

Hawthorne, Nathaniel. The American Notebooks by Nathaniel Hawthorne, ed. Randall Stewart. New Haven: Yale University Press, 1932.

- The Centenary Edition of the Works of Nathaniel Hawthorne, ed. William Charvat, Roy H. Pearce, Claude M. Simpson, et al. 4 vols. Columbus: Ohio University Press, 1963-71.

- The Complete Works of Nathaniel Hawthorne, Intro. George Parsons Lathrop. 12 vols. Boston: Houghton Mifflin, 1883.

- The Engl ish Notebooks by Nathaniel Hawthorne, ed. Randall Stewart. New York: Modern Language Association of America, 1941.

- The Portable Hawthorne, ed. Malcolm Cowley. New York: The Viking Press, 1969. - The Scarlet Letter, eds. Sculley Bradley, Richmond Croom Beatty, and E. Hudson Long. New York: W. W. Norton and Company, 1962.

\section{SECONDARY SOURCES}

Aaron, Daniel. "Emerson and the Progressive Tradition." in Emerson, A Collection of Critical Essays, eds. Milton R. Konvitz and Stephen E. Whicher. Englewood Cliffs: PrenticeHall, 1962.

Abel, Darrel. "The Theme of Isolation in Hawthorne." Personalist, XXXII, Pt. I (Winter 1951), 42-58; Pt. II (Spring 1951), $182-190$.

Arvin, Newton. Hawthorne. New York: Russell and Russell, 1961. - The Heart of Hawthorne's Journals. Boston: Houghton Miffi in Company, 1929. 
Bewley, Marius. The Eccentric Design: Form in the Classic American Novel. New York: Columbia University Press, 1959.

Brownel1, W. C. "The New England Faust." American Prose Masters. New York: Charles Scribner's Sons, 1909, rpt. in Nathaniel Hawthorne. The Scarlet Letter, eds. Sculley Bradley, Richmond Croom Beatty, and E. Hudson Long. New York: W. W. Norton and Company, 1962.

Cady, Edwin H., Frederick J. Hoffman, Roy Harvey Pearce, eds. The Growth of American Literature: A Critical and Historical Survey. New York: American Book Company, 1956.

Carpenter, Frederic I. '"The American Myth' Paradise (To Be) Regained." PMLA. LXXXIV (December 1959), 599-606. (January 1944), pp. 173-180.

$$
\text { "Scarlet A Minus." College English, V }
$$

Chase, Richard. The American Novel and Its Tradition. New York: Doubleday, 1957.

Clough, Wilson 0. The Necessary Earth: Nature and Solitude in American Literature. Austin: University of Texas Press, 1964.

Cowley, Malcolm. "Five Acts of The Scarlet Letter," College English, XIX (October 1957), 11-16.

Crews, Frederick. "The Ruined Wall." in Twentieth Century Interpretations of "The Scarlet Letter," ed. John C. Gerber. Englewood Cliffs: Prentice-Hall, 1968.

- The Sins of the Fathers: Hawthorne's

Psycholonical Themes. New York: Oxford University Press, 1966.

Davidson, Edward. "Dimmesdale's Fall." in Twentieth Century Interpretations of "The Scarlet Letter," ed. John C. Gerber. Englewood Cliffs: Prentice-Hall, 1968.

- "Hawthorne and the Pathetic Fallacy." Journal of English and Germanic Phillology (October 1955), 486-497.

Elder, Marjorie J. Nathaniel Hawthorne: Transcendental Symbolist. Athens: Ohio University Press, 1969.

Fai rbanks, Henry G. The Lasting Loneliness of Nathaniel Hawthorne: A Study of the Sources of Alienation in Modern Man. Albany: Magibooks, 1965. 
'Man's Separation from Nature: Hawthorne's Philosophy of Suffering and Death." Christian Scholar, XLII (March 1959), 51-63.

Feidelson, Charles. "The Scarlet Letter." in Hawthorne Centenary Essays, ed. Roy Harvey Pearce. Columbus: Ohio State University Press, 1964.

Fick, Reverend Leonard J. The Light Beyond: A Study of Hawthorne's Theology. Westminster: The Newman Press, 1955.

Flanagan, John T. "The Durable Hawthorne." Journal of English and Germanic Philology, XLIX (1950), 88-96.

Fogle, Richard Harter. Hawthorne's Fiction: The Light and the Dark. Norman: University of Oklahoma Press, 1952.

- Hawthorne's Imagery: The Proper Light and Shadow in the Major Romances. Norman: University of Oklahoma Press, 1969.

Gerber, John C., ed. Twentieth Century Interpretations of "The Scarlet Letteri": A Collection of Critical Essays, Englewood Cliffs: Prentice-Hall, 1968.

Gorman, Herbert. "Absolved, Redeemed, Damned: A Triangle." Hawthorne: A Study in Solitude. New York: George H. Doran Company, 1929, rpt. in Nathaniel Hawthorne. The Scarlet Letter, eds. Sculley Bradley, Richmond Croom Beatty, and E. Hudson Long. New York: W. W. Norton and Company, 1962.

Gross, Seymour L. "Solitude, and Love, and Anguish: The Tragic Design of The Scarlet Letter." CLA Journal, 111 (March 1960), pp. 154-165, rpt. in Nathaniel Hawthorne. The Scarlet Letter, eds. Sculley Bradley, Richmond Croom Beatty, and E. Hudson Long. New York: W. W. Norton and Company, 1962.

Hal1, Lawrence Sargent. Hawthorne, Critic of Society. Gloucester: Peter Smith, 1966.

Hart, John E. "'The Scarlet Letter': One Hundred Years After." New England Quarterly, XXIII (1950), 381-395.

Hoeltje, Hubert M. Inward Sky: The Mind and Heart of Nathaniel Hawthorne. Durham: Duke University Press, 1962. 
Hoffman, Daniel G. 'Hester's Double Providence: The Scarlet Letter and the Green." Form and Fable in American Fiction. New York: Oxford University Press, 1961, rpt, in Nathaniel Hawthorne. The Scarlet Letter, eds. Sculley Bradley, Richmond Croom Beatty, and E. Hudson Long. New York: W. W. Norton and Company, 1962.

James, Henry. Hawthorne. London: Macmillan and Company 1883.

Katz, Seymour. '"Character,' 'Nature,' and 'Al legory' in The Scarlet Letter," Nineteenth Century Fiction, XxIII (1968), 3-17.

Kaul, A. N. The American Vision: Actual and Ideal Society in Nineteenth Century Fiction. New Haven: Yale University Press, 1963.

- ed. Hawthorne: A Collection of Critical Essays.

Engl ewood Cliffs: Prentice-Hall, 1966.

Konvitz, Milton R. and Stephen E. Whicher, eds. Emerson: A Collection of Critical Essays. Englewood Cliffs: Prentice-Hall, 1962.

Lathrop, George P. A Study of Hawthome. Boston: AMS Press, 1876.

Lathrop, Rose Hawthorne. Memories of Hawthorne. Boston: AMS Press, 1898.

Levin, Harry. The Power of Blackness: Hawthorne, Poe, Melville. New York: Knopf, Inc., 1958.

Levy, Leo B. "The Landscape Modes of The Scarlet Letter." Nineteenth Century Fiction, XxIII (1968), 377-92.

Lewis, R. W. B. The American Adam: Innocence Tragedy and Tradition in The Nineteenth Century. Chicago: University of Chicago Press, 1955.

- "The Tactics of Sanctity." in Hawthorne Centenary Essays, ed. Roy Harvey Pearce. Columbus: Ohio State University Press, 1964.

Loggins, Vernon. The Hawthornes: The Story of Seven Generations of an American Family. New York: Columbia University Press, 1951.

Maclean, Hugh. "Three Epic Quests." in Twentieth Century Interpretations of "The Scarlet Letter," ed. John C. Gerber. Englewood Cliffs: Prentice-Hall, 1968. 
Male, Roy R. Hawthorne's Tragic Vision. New York: W. W. Norton and Company, 1957.

Matthiessen, F. 0. American Renaissance: Art and Expression in the Age of Emerson and Whitman. New York: Oxford University Press, 1941, rpt. in Nathaniel Hawthorne. The Scarlet Letter, eds. Sculley Bradley, Richmond Croom Beatty, and E. Hudson Long. New York: W. W. Norton and Company, 1962.

Michaud, Regis. "Freud and the Triangle." The American Novel Today: A Social and Psychological Study. Boston: Little, Brown and Company, 1928, rpt. in Nathaniel Hawthorne, The Scarlet Letter, eds. Sculley Bradley, Richmond Croom Beatty, and E. Hudson Long. New York: W. W. Norton and Company, 1962.

Miller, Perry, ed. The American Transcendentalists: Their Prose and Poetry. New York: Doubleday and Co., 1957.

- and Thomas H. Johnson. The Puritans. Revised Edition, Vol. 1. New York: Harper and Row, 1963.

Pearce, Roy Harvey, ed. Hawthorne Centenary Essays. Columbus: University of Ohio Press, 1964. Yale Review, XXXxvIII (1948), 487-506.

Pearson, Norman Holmes. "The American Writer and the Feeling for Community." English Studies, XLIII (October 1962), 402-412.

Reid, Alfred S. The Yellow Ruff and "The Scarlet Letter": A Source of Hawthorne's Novel. Gainesville: University of Florida Press, 1955.

Ringe, Donald A. "Hawthorne's Psychology of the Head and Heart." PMLA, LXV (March 1950), 121, 124-5.

Ryskamp, Charles. "The New England Sources of The Scarlet Letter," American Literature, XXXI (November 1959), 257-272.

Spiller, Robert E. The Cycle of American Literature: An Essay in Historical Criticism. New York: Macmillan and Company, 1955.

Stegner, Wallace, ed. The American Novel from James Fenimore Cooper to William Faulkner. New York: Basic Books, 1965. 
Stewart, Randal1. "Puritan Humanism vs. Romantic Naturalism." American Literature and Christian Doctrine. Baton Rouge: Louisiana State University Press, 1958, rpt. in Nathaniel Hawthorne. The Scarlet Letter, eds. Sculley Bradley, Richmond Croom Beatty, and E. Hudson Long. New York: W. W. Norton and Company, 1962.

Strauch, Carl F. "The Problem of Time and the Romantic Mode in Hawthorne, Melville, and Emerson." Emerson Society Quarterly, XXXV (2nd Quarter 1964), 50-60.

Tharp, Louise Hall. The Peabody Sisters of Salem. Boston: Little, Brown and Company, 1950.

Turner, Arlin. Nathaniel Hawthorne: An Introduction and Interpretation. New York: Barnes and Noble, 1961.

Van Doren, Mark. Nathaniel Hawthorne. New York: William Sloane Associates, Inc., 1949.

Wagenknecht, Edward. Nathaniel Hawthorne: Man and Writer. New York: Oxford University Press, 1961.

- "The Soul's Romance, Hawthorne." Cavalcade of the American Novel: From the Birth of the Nation to the Middle of The Twentieth Century. New York: Holt, Rinehart and Winston, 1952.

Waggoner, Hyatt $H$. Nathaniel Hawthorne. Minneapolis: University of Minnesota Press, 1962.

- Hawthorne: A Critical Study. Cambridge: Harvard University Press, 1955.

Walcutt, Charles Child. "The Scarlet Letter and Its Modern Critics." Nineteenth Century Fiction, VII (1953), 251-264.

Warren, Austin. Rage for Order. Chicago: University of Chicago Press, 1948.

White, Sidney Howard. Hawthorne: The Scarlet Letter. Woodbury: Barron's Educational Series, Inc., 1967.

Winters, Yvor. Maule's Curse: Seven Studies in the History of American Obscurantism. Norfolk: New Dl rections, 1938.

Woodberry, George E. Nathaniel Hawthorne. Boston: Houghton Mifflin, 1902. 
Ziff, Larzer. "The Artist and Puritanism." in Hawthorne Centenary Essays, ed. Roy Harvey Pearce. Columbus: Ohio State University Press, 1964. 